\title{
Az Egyesült Államok és az Európai Unió innovációs teljesítményének értékelése és összehasonlítása
}

„E jelentés célja az Egyesült Államok és az Európai Unió innovációs teljesítményének értékelése és összehasonlítása. Az összehasonlításban - szem előtt tartva az innováció mérésekor figyelembe veendő finomságokat is - az európai teljesítményt tekintve elsősorban a tudományos eredmények, a technológiai újítást szolgáló proxik, a tényleges termelés és az export kérdéseit tárgyalja az olyan gazdasági tevékenységek vonalán, amelyek közvetlenül támaszkodnak a tudományos haladásra. A szerzők elemzésének általános eredményei a következőképpen foglalhatók össze: Kétségkívül jelentős különbségek figyelhetők meg a tudományos és műszaki területeken, de Európa a legmagasabb szintű tudományos és innovációs teljesítmények tekintetében, valamint a fizikai és müszaki tudományok egyes területeinek erőssége szempontjából is strukturális jellegű elmaradásban van az USA-hoz képest. Ugyanakkor bizonyítható az európai üzleti vállalkozások széles körü gyengesége is, a nagyobb sikertörténetek mellett...”

Kulcsszavak: innovációs teljesítmény, strukturális elmaradás, tudományos és technológiai tudás, indikátorok

\section{Szerzői információ:}

\section{Giovanni Dosi}

Közgazdász professzor, az olaszországi Pisa városában múködő Scuola Superiore Sant'Anna nevú felsőoktatási intézmény és kutatóintézet munkatársa, a gazdaságtudományi és menedzsmentlaboratórium (Laboratory of Economics and Management, LEM) vezetôje. Érdeklődésének középpontjában a gazdasági fejlődés, a technológiai változás és a növekedés, az ipari szervezôdés, továbbá az adatgyújtés és az adatbecslés metodológiája, valamint a nagyvállalatok pénzgazdálkodása és irányítása áll. Újabb kutatásai az ipari vállalatok tanulási és kiválasztódási folyamataira irányulnak, elsôsorban empirikus olaszországi longitudinális vizsgálatok mikroadatai, illetve a gyógyszeripar PHID-adatbankjai alapján, továbbá a szervezetek problémamegoldásának és irányításának koevolúcióját modellezi. Újabb publikációinak témái között a tudásfelhalmozódás és a térbeli agglomerációs formák mintái, valamint a különféle intézményi architektúrák és viselkedési környezetek által a piac dinamikájára gyakorolt hatások szerepelnek.

E-mail: gdosi@sssup.it

Mauro Sylos Labini

A spanyolországi Alicantei Egyetem vendégprofesszora. Kutatási területei: munkagazdaságtan, az innováció gazdaságtana, továbbá alkalmazott mikroökonometria és társadalmi hálózatok. Az utóbbi években az olaszországi Pisában végzett kutatómunkát. Publikációi számos referált nemzetközi folyóiratban jelennek meg, az alábbi témakörökben: technológiai paradigmák és fejlödésipálya-görbék; a tudomány, a technológia és az ipar közötti kapcsolatok; az „európai paradoxon"; a technológia és a gazdaság gazdaságszociológiai kérdései; a tudományos és technológiai eredmények ipari kiaknázása. Ugyanezeken a szakterületeken számos könyv egyes fejezeteinek társszerzője. 


\section{Patrick Llerena}

A strasbourgi Louis Pasteur Egyetem kutatója és a BETA (Bureau d'Economie Théorique et Appliquée, Strasbourg) megbízott igazgatója. Speciális érdeklődési területe a tudomány gazdaságtana. Kutatási témái: az innováció gazdaságtana, vállalat- és szervezetelmélet, döntéselmélet, technológiapolitika, nemzetközi összehasonlító vizsgálatok. Publikációi 2002 óta számos nemzetközi szakfolyóiratban jelennek meg az alábbi témakörökben: tudomány és innováció, a francia innovációpolitika fejlődése és hatása az egyetemekre, a tudástermelés gazdaságtana, az ipari struktúrák dinamikája és hatékonysága, tudástermelés és -kodifikáció a szervezetközi együttmúködésben, innovatív stratégiák mint a technológiai teljesítmény forrásai.

Email: pllerena@cournot.u-strasbg.fr

\section{Így hivatkozzon erre a cikkre:}

Dosi, Giovanni, Patrick Llerena, Mauro Sylos Labini. „Az Egyesült Államok és az Európai Unió innovációs teljesítményének értékelése és összehasonlítása”.

Információs Társadalom VI, 3. szám (2006): 84-113.

= https://dx.doi.org/10.22503/inftars.VI.2006.3.6

A folyóiratban közölt müvek

a Creative Commons Nevezd meg! - Ne add el! - Így add tovább! 4.0

Nemzetközi Licenc feltételeinek megfelelően használhatók. 
Giovanni Dosi - Patrick Llerena - Mauro Sylos Labini

\title{
Az Egyesült Államok és az Európai Unió innovációs teljesítményének értékelése és összehasonlítása
}

\begin{abstract}
A TrendChart stratégiai múhely (TrendChart Policy Workshop 2005) számára készített szakértói jelentés*
\end{abstract}

2005. június 29.

\section{Bevezetés}

E jelentés célja az Egyesült Államok és az Európai Unió innovációs teljesítményének értékelése és összehasonlítása. Az összehasonlításban - szem elốtt tartva az innováció mérésekor figyelembe veendô finomságokat is - az európai teljesítményt tekintve elsősorban a tudományos eredmények, a technológiai újítást szolgáló proxik, a tényleges termelés és az export kérdéseit tárgyaljuk az olyan gazdasági tevékenységek vonalán, amelyek közvetlenül támaszkodnak a tudományos haladásra. Elemzésünk általános eredményei a következóképpen foglalhatók össze: Kétségkívül jelentôs különbségek figyelhetók meg a tudományos és múszaki területeken, de Európa a legmagasabb szintû́ tudományos és innovációs teljesítmények tekintetében, valamint a fizikai és múszaki tudományok egyes területeinek erôssége szempontjából is strukturális jellegú elmaradásban van az USA-hoz képest. Ugyanakkor bizonyítható az európai üzleti vállalkozások széles körû gyengesége is, a nagyobb sikertörténetek mellett.

Tudomásul kell vennünk, hogy a tudást, az innovációs folyamat alapvető összetevôjét gyakran igen nehéz közvetlen módon mérni. Annak érdekében, hogy koherensen tudjunk értelmezni különböző proxikat és indikátorokat, e jelentés második fejezetében világosan leszögezzük a tudományos és technológiai tudás természetéról és tulajdonságairól, valamint az annak előállítását támogató intézményekról hosszú ideje folyó vitában kialakított álláspontunkat.

Mindamellett, hogy a leegyszerúsítố bemutatás - korlátaiból fakadóan - óhatatlanul determinista módon kapcsolja össze a tudományt a technológiával, tény, hogy a tudományos tudás egyre inkább a technológiai és innovációs teljesítmény egyik fố meghatározójának tekinthető. A 3. fejezet ennélfogva az egyes nemzetek tudományos hatását (scientific Impact of Nations) tárgyalja, bibliometriai adatok felhasználásával.

* Köszönetet mondunk Anthony Arundelnek és Franck Dupontnak, amiért e jelentés előzetes változatait elolvasták és a szöveggel kapcsolatban lényegbevágó megjegyzéseket és javaslatokat tettek. A felelốsség a leírtakért természetesen csakis minket terhel. Az itt közölt tanulmány részben egy friss munkaanyagon alapul, ugyanezen szerzók tollából: a részletesebb kifejtés iránt érdeklốdô olvasókat ehhez irányítjuk (Dosi és tsai, 2005). 
A 4. fejezetben különbséget teszünk a technológiai teljesítmény inputjára és outputjára vonatkozó indikátorok között, annak a rendkívül világos kifejezésére törekedve, hogy ezek mit jelentenek az EU és az USA technológiai képességeinek értékelése szempontjából. Úgy gondoljuk, hogy a külön-külön elvégzett részletes mérések jobb útmutatást adhatnak a döntéshozóknak, mint azok a nem annyira informatív indexek, amelyekben aggregált formában jelennek meg különféle inhomogén indikátorok. ${ }^{1}$ Ebben a fejezetben kiemeljük a felsôoktatási rendszerek néhány megkülönböztetô vonását az USA-ban és Európában.

Az 5. fejezet összekapcsolja az elôzóekben adott elemzéssel azokat a korlátokat és gyengeségeket, amelyeket az európai gazdasági vállalatok mutatnak az innováció és a világgazdaságban folyó verseny terén.

Végül a 6. fejezet konklúzióként megfogalmaz néhány messzire kiható normatív következtetést. Azt állítjuk, hogy Európa hatékony felzárkózásához sokkal kevesebb hangsúlyt kellene fektetni a „hálózatépítés”, ,a helyi környezettel való kölcsönhatások” és , a felhasználók igényeire összpontosított figyelem” különféle formáira és megnyilvánulásaira, amelyekre az európai és nemzeti szintú döntéshozók jelenleg szinte megszállottan koncentrálnak, és ezek helyett sokkal nagyobb figyelmet kell fordítani mind az élvonalbeli kutatások támogatását, mind a másik oldalon az európai nagyvállalati szereplók erôsítését célzó stratégiai intézkedésekre.

\section{Tudomány és technológia: némi segítség az értelmezéshez}

A jelenlegi munka során összegyújtött anyag egyes részeinek értelmezéséhez szükséges világosan megfogalmazni a tudományos és technológiai tudás természetére és tulajdonságaira vonatkozóan általunk alkalmazott átfogó értelmezési keretet. Ezt a célt szem elött tartva, ebben a fejezetben bemutatjuk azt a rendszert, amit StanfordYale-Sussex- (SYS) szintézisnek nevezhetünk, mintegy gyorsírásos jegyzetként az információ gazdaságtanával foglalkozó tanulmányok (köztük Arrow, 1962; Nelson, 1959; David, 1993, 2004) és a technológiai tudás jellegzetes vonásaira koncentráló munkák (köztük Freeman, 1982, 1994; Freeman és Soete, 1997; Nelson és Winter, 1982; Nelson, 1959; Pavitt, 1987, 1999; Rosenberg, 1976, 1982; Winter, 1982, 1987; továbbá Dosi, 1982, 1988) konvergenciájáról. Egy ilyen szintézisben elóször is teljes mértékben fel kell ismerni az információ és a tudás néhány közös vonását - általában, valamint a tudományos és technológiai tudás tekintetében specifikusan is, másodszor pedig különbséget kell tenni a technológiai tudás és az annak elóállításához és kiaknázásához a jelenkori gazdaságokban alkalmazott módszerek speciális vonásai között.

Ami az előzố pontot illeti, mind az információ, mind a tudás jellemezhetố a következő megállapításokkal:

- A közjavak általános tulajdonságai közé tartozik (i) a nem versengó hozzáférés (vagyis az a tény, hogy ha valakinek van egy gondolata, ez nem akadályoz meg másokat abban, hogy ugyanazt gondolják); (ii) a reprodukció és az elosztás ala-

\footnotetext{
${ }^{1}$ Az ilyen indexek általános tárgyalását illetően lásd Archibugi és Coco, 2005.
} 
csony marginális költsége az eredeti létrehozás magas fix költségeihez képest, ami elvileg megnehezíti, hogy másokat kizárjunk az újonnan létrehozott információhoz való hozzáférésból (kivéve az olyan jogi eszközöket, mint például a szerzối jogok és a szabadalmak). [Ez utóbbi megállapítás elsôsorban a szigorú értelemben vett információra vonatkozik.]

- Alapvetố bizonytalanság nyilvánul meg azt illetốen, hogy milyen eltérések adódnak a kutatási tevékenységtól elvárt és az annak eredményeként ténylegesen kapott eredmények között.

- Éberségre van szükség - az elóbbi bizonytalansággal összefüggésben - a kutatás nem várt végsố gazdasági és társadalmi hatásainak azonosítása terén.

- Az eredeti felfedezések és azok „hasznos” alkalmazásai között igen gyakran nagyon hosszú idó múlik el.

A tudományos és még inkább a technológiai tudást azonban egyaránt jellemzi - bár különbözó mértékben - bizonyos fokú hallgatólagosság. Ez a bármilyen felfedezéshez vezetố, elôzetesen meglévő tudásra, valamint a felfedezéssel létrehozott bármilyen kodifikált információ értelmezéséhez és alkalmazásához szükséges tudásra is vonatkozik.

A technológiai tudásra vonatkozóan Pavitt (1987) így ír:

- „A legtöbb technológia specifikus, komplex és kifejlódését tekintve kumulativ jellegü." A specifikus, konkrét jelleg kétféle értelemben nyilvánul meg: „specifikus azoknak a vállalatoknak a számára, ahol az adott technológiai müveleteket elvégzik, és specifikus a termékek és a folyamatok szempontjából is, mivel a költségek legnagyobb részét nem a kutatásra, hanem a fejlesztésre és a termelés müszaki megoldásaira fordítják, s ezek után a

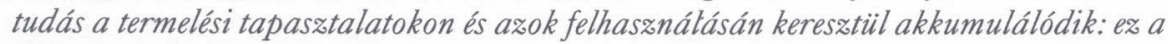
folyamat 'cselekvés útján való tanulásként' és 'hassnálat közbeni tanulásként' vált ismertté" (Pavitt, 1987, 9).

- „A tevékenységek kombinációja a technológiai tudás legnagyobb részének alapvetốen pragmatikus természetét tükrözi. Az elmélet - noha hasznos input-ritkán eléggé robusztus ahhoz, hogy elóre megmondja valamely technológiai úton létrehozott eszköz múködés közben, üzemi feltételek között nyújtott teljesítményét, elegendöen nagy fokú bizonyossággal ahhoz, hogy kikiuszöbölhetö legyen a prototipus létrehozása és annak költséges és idöigényes próbaüzemi tesztelése" (Pavitt, 1987, 9).

Ami a tudományos tudást illeti, egyetértünk Richard Nelsonnak azzal a nézetével, miszerint ,a tudományos alap nagyrész t az állami költségvetésból finanszirozott kutatás termé$k e$ és az ilyen kutatás során létrehozott tudás nagyrészt nyilvános és hoz:áférhetơ a felhasználására épüló potenciális innovációk sæámára. Ez annyit jelent, hogy a technológiai haladás Kapitalista Motorjának piaci része az államilag támogatott tudományos közjavakon nyugszik (Nelson, 2004, 455).

Összefoglalva: az államilag támogatott nyilt tudomány ilyen felfogását megalapozó szemlélet a 20. század jelentôs részében együtt járt (i) a nagyrészt önirányítással múködő és a belső körökben a pályatársak által adott értékelésre támaszkodó tudományos közösség szociológiai szemléletével, (ii) a nem gazdasági természetú motivációs tényezók fontosságát hangsúlyozó közös kultúrával a tudósok körében, és (iii) a kutatási eredmé- 
nyek [kötelezó] közzétételének ethoszával, amit „a gyốztes mindent visz” elvén alapuló precedensszabályok irányítanak. ${ }^{2}$

A fenti megállapításokat bizonyítottnak tekintve azt mondhatjuk, hogy a tudományos tudás és a technológiai innovációk, illetve ezek gazdasági hasznai között meglévố kapcsolatok távolról sem lineárisak, és korántsem egyértelmúen az elóbbitól az utóbbi felé mutatnak. Sok tudós ténylegesen meggyốzóen érvelt amellett, hogy ezek a kapcsolatok mindkét irányban múködnek (Freeman, 1982, 1994; Freeman, 1982, 1994; Rosenberg, 1982; Kline és Rosenberg, 1986; Pavitt, 1999).

Először is, a technológiai innovációk néha megelôzik a tudományt annyiban, hogy a gyakorlati találmányok létrejönnek, mielốtt a tudomány feltárná, hogy azok valójában miért múködnek (erre jó példa a gốzgép). Másodszor, igen gyakori eset, hogy a tudományos előrehaladást a technológiai fejlődés teszi lehetővé, különösen a múszerek terén (gondoljunk például a mikroszkóp fontosságára). Harmadszor, a tudomány és a technológia viszonyában tipikusnak tekinthetốk a jól megfigyelhetốen egymást kiegészítô hatások, ezek azonban „az egyes alkalmazási szektorokban - a tudományos kutatási eredmények közvetlen hasznosságát tekintve, valamint az ilyen eredményeknek és a képzésnek tulajdonított viszonylagos fontosság terén egyaránt - jelentôs változatosságot mutatnak" (Pavitt, 1987, 7).

A tudomány, a technológia és a gazdaság közötti sokoldalú kölcsönhatások nem leegyszerúsítő bemutatása rendkívül hasznos a technológiai innováció forrásainak és folyamatainak megértéséhez. A normatív oldalon azonban a tudománytól a technológia, és onnan a gazdasági haszon felé irányított lineáris modell bírálói (például Kealy, 1996) valószínúleg túl messzire mentek a tudomány szerepének leértékelésében, annak a technológia fejlôdéséhez való viszonylagos hozzájárulását tekintve. A tudomány fontosságának figyelmen kívül hagyása bizonyos mértékig furcsa, adott lévén annak mindent átható jelenléte az utóbbi évtizedekben, amikor az innováció mértékét és ütemét gyakran éppen annak a tudományos bázisnak az ereje szabta meg, amelyre az újítások épültek (Nelson, 1993; Mowery és Nelson, 1999).

\section{Európa tudományos vezető szerepének mítosza}

Az elmúlt évtized végén - a lineáris modell bírálatától is ösztönözve - az Európai Bizottság magáévá tette azt az álláspontot, hogy az EU lemaradása egyes high-tech szektorok és technológiai alkalmazások (elsốsorban az információs és kommunikációs technológiák, valamint a biotechnológia) területén abból következik, hogy Európa nem képes tudományos erejét gazdaságilag nyereséges innovációkban gyümölcsöztetni (EC, 1995). A központi tétel, amit a késóbbiekben mint „európai paradoxont” volt szokás emlegetni, az volt, hogy az EU globálisan vezetố szerepet játszik a legmagasabb szintû tudományos teljesítmények tekintetében, ebból azonban az európai vállalatok

${ }^{2}$ A Bush, 1945; Polányi, 1962 és Merton, 1973 klasszikus megállapításai nyomán született ilyen téziseket illetôen lásd Dasgupta és David, 1994; David, 2004; továbbá Nelson, 2004 újabb értékeléseit, valamint Geuna és tsai, 2003 ezekkel ütköző nézeteit. 
számos ok miatt nem húznak hasznot. ${ }^{3}$ Egy ilyen állítás következményeként nagy hangsúly került az egyetemektól a vállalatokhoz irányuló technológiai transzfer stratégiájára, és általában kevesebb figyelem jutott az inkább spekulatív természetú alapkutatások finanszírozásának mértékére. ${ }^{4}$ Ebben a fejezetben annak a megmutatására törekszünk, hogy az európai kiválóság tétele a tudomány tekintetében nagymértékben téves.

A nemzetek tudományos hatásának (scientific Impact of Nations) mérése nem egyértelmú. Mindenekelótt arról van szó, hogy a bibliometriai elemzés fontos felismeréseket nyújt, de egyúttal hibái is vannak és félrevezetô is lehet. Először is, az adatok legfóbb forrása a Thomson Corporation üzleti vállalkozásaként, eredetileg nem a tudomány minőségének mérésére, hanem gazdasági természetú motivációval létrehozott ISI-adatbank. Másodszor, a citációk összehasonlítása az egyes tudományágak keretei közül kilépve valószínúleg félrevezetô, mivel az idézetek gyakorisága az egyes tudományágakban más és más (például az orvostudományi kutatásokról beszámoló tanulmányokat sokkal többször idézik, mint a matematikaiakat). A publikációkra és a citációkra vonatkozó adatok mindazonáltal - a fenti korlátokat szem elő́tt tartva - feltáró erejúek is lehetnek. Valóban, mint az alábbiakban megmutatjuk, a kialakuló kép messze van attól, hogysem Európa vezetố szerepét mutatná ki a tudományban, hacsak nem akarjuk a publikációk összesített számát a tudományos teljesítmény értelmes mértékének tekinteni (lásd az 1. táblázat elsô oszlopát).

Az 1. táblázat második oszlopában azt láthatjuk, hogy ha a lakosság számát is figyelembe vesszük, akkor Európa állítólagos vezetô pozíciója a publikációk terén (lásd például EC, 2003) megszúnik. ${ }^{5}$

Továbbá a tudományban - a publikációk száma mellett - legalább ugyanilyen fontos a tudományos teljesítmény eredetisége és az érintett kutató közösségekre gyakorolt hatása is. Az ilyen hatás mérésére leggyakrabban alkalmazott két megközelítés a publikációk idézettségének ${ }^{6}$ és a legtöbbször idézett közlemények felsô $1 \%$-ában való részesedésének a vizsgálata.

Mint az 1. táblázat mutatja, az USA meglehetôsen élen jár mindkét indikátor tekintetében. A lakosságra vetített mércével a kiemelkedó EU-teljesítmény még a felét sem éri el az USA eredményének.

Ugyanennek a táblázatnak a 3. és 4. oszlopában a publikációkra, a hivatkozásokra és a közlemények felső $1 \%$-ából a lakosságra vetítve mért részesedésre vonatkozó szá-

\footnotetext{
${ }^{3}$ A fenti állítás általános értékelését illetôen lásd Dosi és tsai, 2005. Ténylegesen úgy tûnik, hogy a bizottság egy újabban közzétett dokumentumában $(\mathrm{EC}, 2004)$ felülvizsgálta az európai tudományos kiválósággal kapcsolatos álláspontját.

${ }^{4}$ Ebben a tekintetben örvendetes újdonságot jelent, hogy a bizottság újabban támogatja egy független Európai Kutatási Tanács létrehozását.

${ }^{5}$ A lakosság létszámával történő normalizáció minden bizonnyal igen durva közelítés, ami egymástól igen különbözố entitásokat átlagol, Svédországtól, Németországtól és az Egyesült Királyságtól indulva az országok során át Olaszországig, Görögországig és Portugáliáig (csupán az EU-15 tagállamok körében maradva). Tény azonban, hogy az USA tekintetében is átlagokkal találkozunk, Massachusettstól és Kaliforniától Mississippi és Idaho államokig bezárólag.

${ }^{6}$ Ezek általában erốsen elferdítik a képet: csupán néhány publikációra történik igen sok hivatkozás, míg a közlemények túlnyomó többségét egyáltalán nem idézik.
} 
mokat lebontjuk két komponensre: az egyetemi kutatók tudományos tevékenységének mértékére (vagyis az egy egyetemi kutatóra jutó teljesítményre) ${ }^{7}$ és az egyetemi kutatók számának a lakosság létszámához viszonyított arányára. A táblázat világosan megmutatja, hogy az USA vezetô pozíciója inkább a tudományos termelékenységnek tulajdonítható, mintsem a kutatók puszta számának. Hasonló eredmények nyerhetók a kutatási teljesítmények egyéb indikátorokat használó, másféle méréseiból is (lásd Dosi és tsai, 2005).

1. táblázat. Közlemények és hivatkozások, a lakosság lélekszámával és az egyetemi kutatók számával súlyozva

\begin{tabular}{|l|c|c|c|c|c|c|}
\hline & Közlemények & $\frac{\text { Közlemények }}{\text { lakosság }}$ & $=$ & $\frac{\text { Közlemények }}{\text { kutatók }}$ & $\mathrm{x}$ & $\frac{\text { Kutatók }}{\text { lakosság }}$ \\
\hline USA & 1265808 & 4,64 & & 6,80 & & 0,68 \\
\hline EU-15 & 1347985 & 3,60 & & 4,30 & & 0,84 \\
\hline USA & Hivatkozások & $\frac{\text { Hivatkozások }}{\text { lakosság }}$ & & $\frac{\text { Hivatkozások }}{\text { kutatók száma }}$ & $\frac{\text { A kutatók száma }}{\text { lakosság }}$ \\
\hline EU-15 & 10850549 & 39,75 & & 58,33 & & 0,68 \\
\hline & 8628152 & 23,03 & & 27,52 & 0,84 \\
\hline USA & $\begin{array}{c}\text { A legtöbbet idézett } \\
1 \% \text {-nyi közlemény }\end{array}$ & $\begin{array}{c}\text { A legtöbbet idézett } \\
1 \% \text {-nyi közlemény }\end{array}$ & $\begin{array}{c}\text { A legtöbbet idézett } \\
1 \% \text {-nyi közlemény }\end{array}$ & $\frac{\text { Kutatók }}{\text { lakság }}$ \\
\hline EU-15 & 23723 & 0,09 & 0,13 & 0,04 & 0,68 \\
\hline
\end{tabular}

Megjegyzések: számításaink a King (2004) és az OECD (2004a) által közölt adatokon alapulnak. A közlemények, a hivatkozások, valamint a legtöbbet idézett 1\%-nyi közlemények számát jelző adatok az 1997-2001 idốszakra vonatkoznak. A lakosság lélekszámát (ezer fóben megadva) és az egyetemi kutatók számát (teljes munkaidóben foglalkoztatott kutatókra átszámítva) az 1999. évre adtuk meg. Minden hivatkozott tanulmányt egyszer veszünk számításba minden olyan országra nézve, amelyben valamelyik szerző dolgozik. Az EU-15-re összesített adatokat a többszörös beszámítás elkerülése végett oly módon korrigáltuk, hogy a pontos összegek megállapításakor a több európai országból származó szerzók tanulmányait csak egyszer vettük figyelembe.

Az európai kutatás minôségének feltárt interdiszciplináris változatossága - az általános gyengeségek dacára - további szigorú elemzést kíván meg: az USA-ban és az EU-ban az egyes tudományágakban elért eredmények összehasonlítása könnyebb és többet mondó lehet, mint az átfogó értékelés. Az Egyesült Királyság országos kutatási statisztikáiban használatos 68 tudományági egységet hét tágabb kategóriában aggregálva (klinikus orvostudomány, nemklinikus orvostudomány és egészségügy, biológiai tudományok, környezettudomány, matematika, természettudományok, múszaki tudományok) King (2004) világosan megállapítja az USA fölényét az élet- és orvostudományokban, míg Európa kissé jobban teljesít a természettudományok és a múszaki tudományok terén (lásd 1. ábra). Néhány fontos, jól megkülönböztetố mintázat fel-

\footnotetext{
${ }^{7}$ Ideális esetben az adatokat ellenôrizni kellene azokra a nem akadémiai/egyetemi kutatókra nézve is, akik tudományos folyóiratokban publikálnak.
} 
bukkan az EU-n belül is: Franciaország például erốs a matematikában, míg Németország és az Egyesült Királyság viszonylag jó teljesítményt mutat fel a természettudományok, illetve az élettudományok területén. ${ }^{8}$

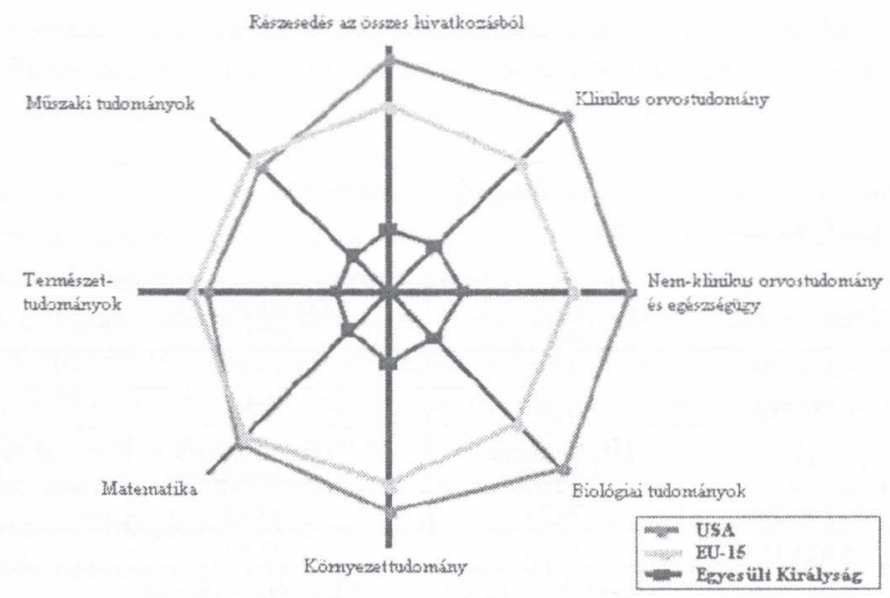

1. ábra. A különbözó tudományokban felmutatott erösségek

Megjegyzés: az ábra a kutatás „lábnyomát” a hivatkozásokból való részesedés alapján mutatja. Az origótól való távolság jelzi a hivatkozásokból való részesedést. Az adatok forrását (ISI Thomson) és a részleteket illetôen lásd King (2004).

Az általános tanulság tehát távol áll bármilyen általánosított európai vezetố szerep megállapításától. Éppen ellenkezóleg: Európa strukturális elmaradása figyelhetố meg a legmagasabb szintû tudomány terén az USA-hoz képest, néhány szektorális kivétellel a természettudományokban és a múszaki tudományokban. Nézetünk szerint az USA-hoz való felzárkózás tekintetében a dinamikusabb innovációs teljesítmény alapvetően szükséges feltételei közé tartozik mind az alapkutatások nagyvonalúbb állami támogatása, mind az európai felsőoktatási rendszerek átfogó reformja.

\section{Gyengébb müszaki teljesítmények}

Ahhoz, hogy az Egyesült Államokhoz viszonyítva részletesen megvizsgálhassuk az Európai Unió technológiai és innovációs teljesítményét, különbséget kell tennünk a tudomány és a technológia terén eszközölt beruházások között, mivel az elóbbinek az inputjai tipikusan az oktatási, illetve a kutatási és fejlesztési költségekben jelennek meg, az utóbbiak eredményei pedig többnyire a szabadalmakkal közelíthetók meg. Tanulmányunk nem foglalkozik kifejezetten azzal a szereppel, amit az innovációt finanszírozó különbözó intézmények játszanak, sem pedig konkrétan a vállalkozási tốkével. Valójában úgy véljük, hogy az u tóbbinak a fontosságát az USA országos innovációs rend-

${ }^{8}$ Ennek részletesebb kifejtését illetôen lásd King, 2004. 
szerének sikerében mind a tudósok, mind a politikai döntéshozók lényegesen túlbecsülték. Éppen ellenkezóleg: nagymértékben osztjuk Anne Lean Saxenian (1996) nézeteit, aki a különféle pénzügyi közvetítók szerepének fontosságát regionális klaszterekben vizsgálva azt hangsúlyozza, hogy a vállalkozási tóke beáramlása valószínúleg inkább a következménye a high-tech szektor fejlődésének, mintsem annak előfeltétele. Saxenian meggyớzően érvel továbbá amellett, hogy gyakorlatilag minden olyan stratégia, ami az innováció ösztönzését a vállalkozási tóke bevitelével kívánta előmozdítani, nagymértékben hatástalan maradt.

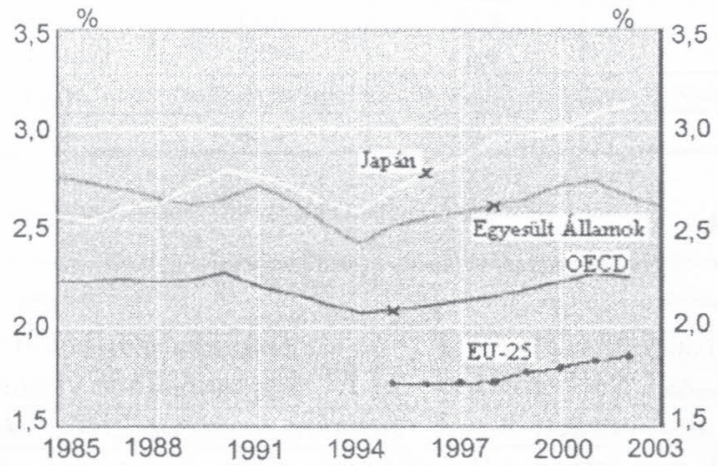

2. ábra. A $K+F$-re fordított bruttó belföldi kiadások a GDP százalékában

Forrás: OECD 2004a

\subsection{Kutatási és fejlesztési beruházások}

A leggyakrabban idézett indikátor, amely rámutat Európa gyengeségére az innovatív törekvések terén, valószínúleg a $\mathrm{K}+\mathrm{F}$-re fordított bruttó belföldi kiadások alacsonyabb szintje a GDP \%-ában kifejezve (Gross Domestic Expenditur on R\&D, GERD), amit a 2. ábra mutat.

Annak megértéséhez, hogy mi okozza az európai gyengeségeket, továbbá az általános $\mathrm{K}+\mathrm{F}$ kiadások növelésére irányuló stratégiai intézkedések irányvonalának meghatározásához is sokatmondó lehet azoknak a dimenzióknak a kiemelése, amelyek közvetlenebb módon reagálnak a politikai jellegú változásokra. A 2. táblázat a $\mathrm{K}+\mathrm{F}$-re fordított állami finanszírozású általános kiadásokat mutatja a GDP \%-ában, az EU kiválasztott országai és az USA esetében. Az EU-25 aggregált teljesítménye - még akkor is, ha a francia és a német kormány az amerikaival összehasonlítható nagyságú összegeket ruház be ebben a szektorban - elmarad az Egyesült Államokétól. Az a kijelentés, miszerint a $\mathrm{K}+\mathrm{F}$ tevékenységek állami finanszírozása Európában magasabb szintû lenne, mint az USA-ban, egyszerúen alaptalan. ${ }^{9}$

${ }^{9} \mathrm{Ez}$ a félreértés rendszerint az államilag finanszírozott $\mathrm{K}+\mathrm{F}$ tevékenységnek az összes $\mathrm{K}+\mathrm{F}$ tevékenységhez viszonyított részarányát kifejezố adatok használatán alapul, amelynek gazdasági szempontból nincs sok értelme. Értelmes, sokatmondó adatok úgy nyerhetók, hogy a K + F-re fordított összegeket az egész gazdasághoz viszonyítva normalizáljuk. 
2. táblázat. Az államilag finanszírozott GERD a GDP\%-ában

\begin{tabular}{|l|c|c|c|c|}
\hline \multicolumn{1}{|c|}{ Országok } & $\mathbf{1 9 9 8}$ & $\mathbf{1 9 9 9}$ & $\mathbf{2 0 0 0}$ & $\mathbf{2 0 0 1}$ \\
\hline Finnország & 0,87 & 0,94 & 0,89 & 0,87 \\
\hline Franciaország & 0,81 & 0,80 & 0,84 & 0,82 \\
\hline Németország & 0,81 & 0,78 & 0,78 & 0,79 \\
\hline Olaszország & 0,51 & $\ldots$ & $\ldots$ & $\ldots$ \\
\hline Spanyolország & 0,35 & 0,36 & 0,36 & 0,38 \\
\hline Svédország & $\ldots$ & 0,89 & $\ldots$ & 0,90 \\
\hline Egyesült Királyság & 0,55 & 0,55 & 0,53 & 0,53 \\
\hline EU-15 & 0,65 & 0,65 & 0,65 & 0,66 \\
\hline EU-25 & 0,63 & 0,63 & 0,63 & 0,63 \\
\hline Egyesült Államok & 0,79 & 0,76 & 0,71 & 0,76 \\
\hline
\end{tabular}

Forrás: OECD, 2004a

Megjegyzés: Az olaszországi arányszám 1996-ra vonatkozik.

Az államilag finanszírozott $\mathrm{K}+\mathrm{F}$ több komponens szerint kategorizálható. Mint a 2. táblázat mutatja, az USA kormánya - az EU kormányaihoz viszonyítva - többet költ mind a vállalatok által végzett $\mathrm{K}+\mathrm{F}$ (businnen enterprise $R \& D, B E R D$ ) támogatására, mind pedig a $\mathrm{K}+\mathrm{F}$ más formáira (felsôoktatás, állami kutatóintézetek stb.). A különbség legnagyobb része azonban az államilag finanszírozott $B E R D$ terén mutatkozik.

Ami az utóbbit illeti, az a jól ismert felismerés, hogy a magántóke felhasználásával folyó $\mathrm{K}+\mathrm{F}$ tevékenység a társadalom szempontjából túlságosan alacsony szintú, nem eredményez világosan kirajzolódó következtetéseket az ipari technológiák támogatását célzó konkrét politikai intézkedésekre vonatkozóan. A központi problémát itt annak az elkerülése jelenti, hogy állami alapokból finanszírozzanak olyan $\mathrm{K}+\mathrm{F}$ beruházásokat, amelyek állami szubvenciók nélkül is megvalósultak volna. ${ }^{10}$

Az államilag finanszírozott $B E R D$-re vonatkozó adatok alábecsülik továbbá az ipari technológiák támogatására fordított állami támogatás teljes összegét, mivel az nem tartalmazza (i) a kormányok által erre a célra alkalmazott valamennyi pénzügyi eszközt (pl. a fiskális ösztönzóket és hiteleket), és (ii) a más szektorokban állami finanszírozással az ipar támogatására végzett $\mathrm{K}+\mathrm{F}$ tevékenységet. Az ipari technológiai innovációk állami támogatásának általánosabb megfogalmazásban három tág kategóriája határozható meg, amelyeket a 4. táblázat foglal össze: elôször is mindazok a programok, amelyek az ipari vállalatokat a költségek csökkentésével, különféle pénzalapok, hitelek és fiskális intézkedések révén $\mathrm{K}+\mathrm{F}$ tevékenység folytatására ösztönzik; másodszor a $\mathrm{K}+\mathrm{F}$ tevékenység finanszírozására az ipari vállalatoknak különféle támogatási programok keretében juttatott állami kifizetések, különös tekintettel a honvédelmi és úrkutatási célokra; és harmadszor azoknak a „kutatási infrastruktúráknak” az állami támogatása, amelyek kifejezetten ipari fejlesztésre irányulnak, ám nem foglalnak magukba semmiféle magánvállalatokhoz irányuló pénzügyi transzfert (idetaroznak például az állami intézmények és az egyetemek által vállalt alkalmazott kutatások).

${ }^{10}$ Lásd a Research Policy 2000 különszámát [29 (4-5)]. 
3. táblázat. A $K+F$-re fordított állami támogatások megoszlása 2001-ben: BERD és nem BERD

\begin{tabular}{||l|c|c|c|c|}
\hline \multicolumn{1}{|c|}{ Ország } & $\begin{array}{c}\text { Államilag } \\
\text { finanszírozott } \\
\text { BERD }\end{array}$ & A GDP \%-a & $\begin{array}{c}\text { Államilag } \\
\text { finanszírozott } \\
\text { nem-BERD }\end{array}$ & A GDP \%-a \\
\hline EU-15 & 9369 & 0,10 & 53352 & 0,56 \\
\hline EU-25 & 9868 & 0,09 & 55073 & 0,52 \\
\hline Egyesült Államok & 18849 & 0,19 & 57533 & 0,57 \\
\hline
\end{tabular}

\section{Megjegyzések:}

Az adatok számításának alapja: OECD 2004a

A bruttó kiadások millió USD-ben vannak megadva, 2000. évi árfolyamon számítva -állandó árak és PPP.

4. táblázat. Az ipari technológiák állami támogatásának fó kategóriái

\begin{tabular}{|l|l|l||}
\hline \multicolumn{1}{|c|}{ Pénzügyi ösztönzók } & \multicolumn{1}{c|}{$\begin{array}{c}\text { Szerzódések } \\
\text { és felvásárlások }\end{array}$} & \multicolumn{1}{c|}{ Infrastruktúrák } \\
\hline 1. Fiskális ösztönzók & 1. Honvédelem & 1. Intézmények \\
\hline 2. Pénzalapok & 2. Úrkutatás & 2. Felsóoktatás \\
\hline 3. Más ösztönzók & 3. Egyéb szerződések & 3. Terjesztés \\
\hline
\end{tabular}

Forrás: Young (2001).

A fentiekre vonatkozóan sajnos (még az iparosodott országokban is) alig állnak rendelkezésre nemzetközi statisztikák. A harmadik ábra egy előzetes felmérés eredményeit mutatja be, amelyet az OECD végzett az ipari technológiákra fordított/becsült állami támogatás egyes kategóriáinak megállapítására, az ipari GDP \%-os arányát vizsgálva (Young, 2001).

Még ha az eredményeket a vizsgálat előzetes jellegére való tekintettel bizonyos óvatossággal kell is kezelnünk, annyi mindenesetre világosan látható, hogy a támogatások szerkezeti mintái az egyes országokban jelentôsen különböznek egymástól. Az ipari technológiákra jutó szövetségi támogatást - különösen az USA-ban - szinte teljes egészében a vállalatok kapják (úgy túnik, hogy az egyetemek nem részesülnek ipari technológiai kutatások céljára biztosított állami pénzalapokban), és a támogatás legnagyobb része célirányos szerződéseken és felvásárlásokon keresztül történik. Ami az EU-országokat illeti, Franciaországban és az Egyesült Királyságban az ilyen célra irányuló szerzôdések szintén viszonylag fontosak, míg Németországban és Hollandiában a pénzalapok egyenletesen oszlanak meg a három kategória között. Az egész EU-25 csoportra vonatkozó adatok természetesen rendkívül hasznosak lennének. 


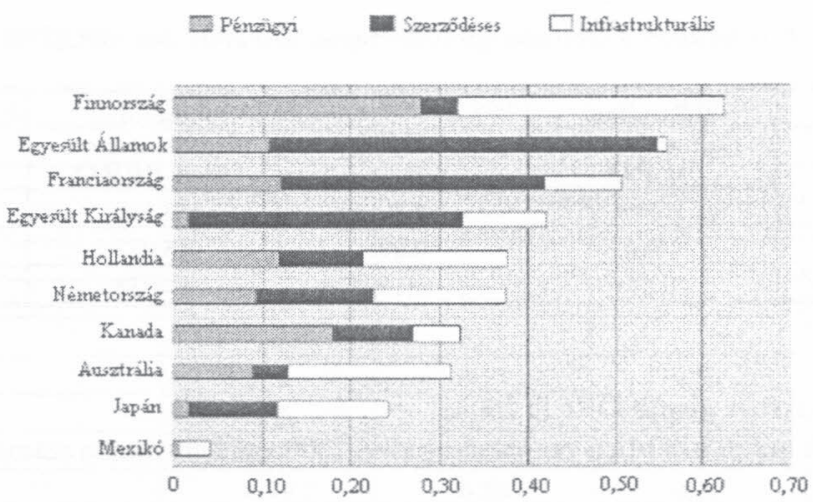

3. ábra. Az ipari technológiákra forditott állami támogatás a belföldi ipari termék (Domestic Product of Industry, DPI) százalékában (becsült adatok)

Megjegyzés: 1997. évi adatok vagy a legközelebbi év elérhetô adatai.

Forrás: Young, 2001.

Az EU és az USA közötti szakadék még szélesebb az ipar által finanszírozott $\mathrm{K}+$ F-re jutó bruttó kiadások tekintetében (a GDP \%-ában kifejezve, lásd az 5. táblázatot), és ezen a téren - az egyes országokban kialakult változatos minták dacára - nincs jele a felzárkózásnak. Az ipari finanszírozású $\mathrm{K}+\mathrm{F}$ aszimmetriáit magyarázó tényezóket a tudástermelésre és annak az ipari szektorokban való elterjesztésére irányuló erófeszítések jelentős és állandó különbségeiben fedezhetjük fel.

5. táblázat. Iparilag finanszirozott GERD a GDP \%-ában

\begin{tabular}{|l|c|c|c|c|}
\hline \multicolumn{1}{|c|}{ Ország } & 1998 & 1999 & 2000 & 2001 \\
\hline Finnország & 1,84 & 2,16 & 2,39 & 2,41 \\
\hline Franciaország & 1,16 & 1,18 & 1,14 & 1,21 \\
\hline Németország & 1,44 & 1,59 & 1,65 & 1,65 \\
\hline Olaszország & 0,43 & $\ldots$ & $\ldots$ & $\ldots$ \\
\hline Spanyolország & 0,44 & 0,43 & 0,47 & 0,45 \\
\hline Svédország & $\ldots$ & 2,47 & $\ldots$ & 3,07 \\
\hline Egyesült Királyság & 0,86 & 0,91 & 0,91 & 0,88 \\
\hline EU-15 & 0,98 & 1,04 & 1,06 & 1,08 \\
\hline EU-25 & 0,93 & 0,98 & 1,00 & 1,02 \\
\hline Egyesült Államok & 1,70 & 1,77 & 1,88 & 1,84 \\
\hline
\end{tabular}

Forrás: EC 2004. Az olaszországi adat 1996-ra vonatkozik.

Az általános $\mathrm{K}+\mathrm{F}$ beruházásokkal kapcsolatos utolsó megjegyzésünk az ipar által finanszírozott felsőoktatási $\mathrm{K}+\mathrm{F}$ (Higher Education R\&D, HERD) részarányára vonatkozik. ${ }^{11}$

${ }^{11}$ A HERD-re jutó beruházások aránya a GDP \%-ában történetesen nagyon hasonló az USA és az EU-25 országok esetében (2001-ben 0,40, illetve 0,39\%). 
Ez az utóbbi egyike azoknak a csekély számú megbízható indikátoroknak, amelyek az egyetemek és a gazdasági élet együttmúködésének fontosságát jelzik, és ebben az esetben az USA-EU összehasonlítás ellentmond annak a konvencionális meggyőződésnek, miszerint az USA-ban erősebb pénzügyi kapcsolatok vannak az egyetemek és az iparvállalatok között. Mint a 6. táblázat mutatja, az egyetemi $\mathrm{K}+\mathrm{F}$-re fordított magánbefektetések - miközben mindenütt alacsonyak - az EU-ban valamelyest magasabbak, mint az USÁ-ban. Hasonló eredményekre jutunk akkor is, ha a privát szektor éves befektetéseit vizsgáljuk az állami kutatási szektorban, vagyis a felsőoktatásban és az állami $\mathrm{K}+\mathrm{F}$ intézményekben (King, 2004).

6. táblázat. $A z$ ipar által finanszírozott felsóoktatási $K+F$-re jutó kiadások (HERD) részaránya

\begin{tabular}{|l|r|r|r|r|}
\hline \multicolumn{1}{|c|}{ Országok } & $\mathbf{1 9 9 8}$ & $\mathbf{1 9 9 9}$ & $\mathbf{2 0 0 0}$ & $\mathbf{2 0 0 1}$ \\
\hline Belgium & 11,1 & 10,5 & 11,8 & 12,7 \\
\hline Franciaország & 3,4 & 3,4 & 2,7 & 3,1 \\
\hline Németország & 10,5 & 11,3 & 11,6 & 12,2 \\
\hline Spanyolország & 7,0 & 7,7 & 6,9 & 8,7 \\
\hline Egyesült Királyság & 7,3 & 7,3 & 7,1 & 6,2 \\
\hline EU-15 & 6,4 & 6,5 & 6,6 & 6,8 \\
\hline EU-25 & 6,4 & 6,5 & 6,5 & 6,7 \\
\hline Egyesült Államok & 6,1 & 6,1 & 6,0 & 5,5 \\
\hline
\end{tabular}

Forrás: EIS és OECD (2004)

Igen tanulságos lehet megmérni - hasonlóan a tudástermeléshez - mind az állami, mind a privát befektetések viszonylagos fontosságát a különféle tudományos és múszaki területeken, illetve az egyes ipari szektorokban. Még ha nem is minden akadémiai $\mathrm{K}$ + F tevékenység részesül állami támogatásban, mint említettük, érdekes gyakorlat az akadémiai $\mathrm{K}+\mathrm{F}$ teljesítmény lebontása az egyes kutatási területek szerint. A 7. táblázat bemutatja, hogy bizonyos EU-országok $\mathrm{K}+\mathrm{F}$ kiadásaik nagyobb hányadát szentelik a múszaki és társadalomtudományokra, valamint a humán tudományokra, mint az USA. Ezzel szemben az USA akadémiai $\mathrm{K}+\mathrm{F}$ erőfeszítései inkább az orvostudományokra és a természettudományokra koncentrálódnak. Ez utóbbi összhangban áll mind az elốzó fejezetben bemutatott tudományos bizonyítékokkal, mind pedig azzal a jól ismert ténnyel, hogy az Egyesült Államok nagy hangsúlyt fektet az egészségügy fejlesztésére, valamint a biológiai és orvostudományokra.

7. táblázat. A HERD megoszlása országonkéntés tudományos, illetve múszaki teriiletek szerint, 1998 vagy 1999

\begin{tabular}{|l|c|c|c|c|c|c|}
\hline \multicolumn{1}{|c|}{ Országok } & NS\&E & Term.tud. & Müsz.tud. & Orvostud. & Agrártud. & Humán tud. \\
\hline Németország & 78,4 & 29,2 & 20,3 & 24,7 & 4,2 & 20,6 \\
\hline Spanyolország & 77,9 & 38,4 & 18,7 & 14,2 & 5,6 & 22,1 \\
\hline Svédország & 76,3 & 21,0 & 21,9 & 27,4 & 6,1 & 17,6 \\
\hline Egyesült Államok & 93,7 & 41,8 & 15,5 & 29,1 & 7,4 & 6,3 \\
\hline
\end{tabular}

Megjegyzés: NS\&E = természettudományok és múszaki tudományok együtt.

Forrás: Az OECD tudományos és technológiai adatbázisa,

(Science and Technológy Statistics Database, 2003) 
Az államilag támogatott $B E R D$ mellett egy hasznos további kiegészítő indikátor is jelzi az ipari K + F állami támogatásának, vagyis az állami költségvetésból származó K + $\mathrm{F}$ beszerzéseknek és kiadásoknak a mértékét (Government Budget Appropriations or Outlays for RED, GBAORD).

Az alapvetố különbség e kettố között az, hogy míg az elóbbit a ténylegesen államilag támogatott $\mathrm{K}+\mathrm{F}$ tevékenységet végzố vállalatok által szolgáltatott adatokból számítják, az utóbbinak a számítása az országos költségvetésekból származó adatok alapján történik. A GBAORD-adatok - tekintettel a K + F kategorizálására alkalmazott kritériumok változatosságára és heterogeneitására az egyes országokban - valószínúleg kevésbé pontosak, ${ }^{12}$ ám megvan az az elônyük, hogy konkrét célokkal kapcsolhatók össze. A jelen tanulmány céljai szempontjából tanulságos látni az EU és az USA között mutatkozó fóbb különbségeket.

A 8. táblázat a honvédelem és bizonyos polgári $\mathrm{K}+\mathrm{F}$ tevékenységek kategóriái szerint bontja le a $G B A O R D$ adatait. Az USA költségvetésének jóval nagyobb hányadát szenteli államilag támogatott honvédelmi $\mathrm{K}+\mathrm{F}$ tevékenységre. Valószínúleg ez rejlik a szerzódések és a felvásárlások fontosságát vázoló adatok mögött is, lásd 3. ábra.

8. táblázat. A GBAORD különféle összetevóinek részaránya, \%-ban

\begin{tabular}{|l|c|c|c|c|}
\hline & $\mathbf{K}+\mathrm{F}$ & \multicolumn{3}{|c|}{$\mathrm{K}+\mathrm{F}$ a polgári költségvetésben } \\
\hline & $\begin{array}{c}\text { a honvédelmi } \\
\text { költségvetésben }\end{array}$ & gazd. fejlesztés & $\begin{array}{c}\text { eü. + körny. } \\
\text { védelem }\end{array}$ & űrprogram \\
\hline EU-15 & 15,2 & 17 & 14 & 5 \\
\hline EU-25 & 14,9 & 17 & 13 & 5 \\
\hline Egyesült Államok & 55,1 & 5 & 26 & 8 \\
\hline
\end{tabular}

Megjegyzés: A számok az USA esetében a 2004, az EU-15 és az EU-25 esetében pedig a 2001. évre vonatkoznak.

Forrás: OECD, 2004a.

Ha a gazdasági vállalatok $\mathrm{K}+\mathrm{F}$ tevékenységét összetevôire bontjuk, még a high-tech iparágak is jelentốs különbségeket mutatnak. Ez viszont részben a technológiai lehetôségek interszektorális különbségeinek, részben pedig annak a módnak tulajdonítható, ahogyan ez utóbbiakat kezelik, egyes iparágakban ugyanis csupán a formális $\mathrm{K}+\mathrm{F}$ tevékenységeket sorolják ide, másokban pedig a kimutatások a munka közbeni, használat közbeni, illetve az ellátókkal és a fogyasztókkal való együttmúködés közbeni tanulás informálisabb folyamatait is magukban foglalják. ${ }^{13}$

Ebben a tekintetben Európára nézve történetesen hátrányos helyzetet idéz elô a $B E R D$ számításának úgynevezett , kompozit” hatása, mivel az viszonylag erốs a technológiák terén (pl. a gépészmérnöki tudományokban), ahol a kutatási és fejlesztési törekvések jelentốs részét nem számítják a „K + F tevékenységek” közé. Az Európa lemara-

${ }^{12}$ Részletesebben lásd Young, 2001.

${ }^{13}$ Az óriási mennyiségú erre vonatkozó szakirodalomból erre a pontra nézve lásd Dosi, 1988; Klevorick, 1995; Malerba, 2004. 
dását mutató szakadék azonban még az interszektorális tevékenységek ellenôrzése után sem tưnik el teljesen. ${ }^{14}$

A K + F terén eszközölt pénzügyi befektetések mellett a magas iskolai végzettségú és szakmailag jól képzett emberi erőforrások is igen fontos inputot jelentenek az innovációs folyamatban. Az emberek azonban nemcsak létrehozzák, hanem hordozzák és továbbítják is a tudást, és ennélfogva néhány szerző hangsúlyozza, hogy a jól képzett tudósok és kutatók ugyanakkor az egyik legfontosabb eredményét is alkotják az egyetemek és az alapkutatások állami támogatásának (lásd pl. Pavitt, 2001 és Florida, 1999).

Az európai teljesítményt illetően - a K + F-fel kapcsolatos adatokkal összhangban, bár néhány kivétel mellett - lehangoló helyzetkép rajzolható fel általában az emberi tôke létrejöttét tekintve is, akár az egyetemet végzett személyeknek a lakosság megfelelô korcsoportjában kitett hányadával, akár pedig a kutatóknak a foglalkoztatott teljes munkaeróhöz viszonyított arányával mérve azt. Az indikátoroknak ez a kétféle csoportja természetesen összefügg, de míg az első fóleg az egyéni választások és az oktatási intézmények eredményeit mutatja, az utóbbi inkább általában az oktatási rendszer és a gazdaság termelési struktúrája közötti koordinációs mechanizmusoktól függ. A 9. táblázat azt mutatja, hogy az EU az adott korcsoportokra vetítve az USA-val összehasonlítható számú új diplomás szakembert „termel” a tudományok és a technológia területén, míg a felsőfokú végzettségú személyek részarányát, illetve az összes kutatók ezer foglalkoztatott dolgozóra vetített számát tekintve elmaradásban van.

9. táblázat. A felsöfokú végzettségü személyek részaránya (a 25-64 éves korosztály \%-ában), a tudományos és mǘszaki végzettségü friss diplomások száma (ezer 20-29 éves lakosra vetítve), és az összes kutatók száma (ezer foglalkoztatott dolgozóra vetítve)

\begin{tabular}{||l|c|c|c|c|c|c|c|c|c||}
\hline \multirow{2}{*}{ Országok } & \multicolumn{3}{|c|}{ Felsófokú oktatás } & \multicolumn{3}{c|}{ Tud. és mũsz. diplomá- } & \multicolumn{4}{c||}{ Kutatók } \\
\cline { 2 - 13 } & 1999 & 2001 & 2003 & 1999 & 2001 & 2003 & 1999 & 2001 & 2003 \\
\hline Franciaország & 20,9 & 22,6 & 23,1 & 19,0 & 20,2 & 22,2 & 6,8 & 7,2 & 7,5 \\
\hline Németország & 23,0 & 23,5 & 24,3 & 8,6 & 8,0 & 8,4 & 6,7 & 6,8 & 6,9 \\
\hline Olaszország & 9,5 & 10,0 & 10,8 & 5,5 & 6,1 & 7,4 & 2,9 & 2,8 & $\ldots$ \\
\hline Spanyolország & 21,1 & 23,6 & 25,2 & 9,6 & 11,3 & 12,6 & 4,0 & 5,0 & 5,1 \\
\hline Svédország & 28,5 & 25,5 & 27,2 & 9,7 & 12,4 & 13,9 & 9,6 & 10,6 & $\ldots$ \\
\hline Egyesült Királyság & 27,5 & 28,7 & 30,6 & 15,6 & 19,5 & 21,0 & 5,5 & $\ldots$ & $\ldots$ \\
\hline EU-15 & 20,5 & 21,5 & 22,5 & 10,2 & 11,9 & $\ldots$ & 5,6 & 5,9 & $\ldots$ \\
\hline EU-25 & 19,4 & 20,1 & 21,2 & 9,4 & 11,0 & $\ldots$ & 5,3 & 5,6 & 5,8 \\
\hline Egyesült Államok & 35,8 & 37,3 & 38,1 & 9,3 & 9,9 & 10,9 & 8,6 & $\ldots$ & $\ldots$ \\
\hline
\end{tabular}

Megjegyzés: Az USA-ra vonatkozó indikátor a felsőfokú tanulmányokat végzettekre nézve 2003ban a 2002. évre vonatkozik. Az olaszországi adat a tudományos és múszaki diplomásokra nézve 2003-ban 2002-re, az EU-25 esetében pedig ugyanez az adat a 2000. évre vonatkozik. Az Egyesült Királyság kutatóinak számát jelzố adat 1998-ra vonatkozik.

Forrás: EIS, 2005, indikátorok és OECD, 2004a. 


\subsection{A felsốoktatási rendszerek}

Ennél a pontnál érdemes foglalkoznunk azokkal a természetesen számításba veendő tényezókkel és megkülönböztetô jellemvonásaikkal, amelyek megmagyarázhatják az USA vezetố szerepét mind a tudományos produktivitás, mind a magasabb arányú fốiskolai és egyetemi beiskolázás terén, vagyis magukkal a felsốoktatási intézményekkel. Az USA felsőoktatási rendszerének összehasonlítása az európaival azonban nehéz feladat, legalább két okból: Először is, az európai országoknak - függetlenül a közös modell elfogadása irányában összetartó újabb kísérleteiktôl - egymástól meglehetôsen különbözố és a változásoktól idegenkedô, sốt valósággal irtózó, idioszinkráziás felsôoktatási rendszereik alakultak ki. Másodszor, a felsốoktatási rendszerek struktúrájának nemzetközi összehasonlítását lehetôvé tevő adatok meglepően hiányosak még a fejlett ipari gazdaságokban is. Mindazonáltal fontos tanulságok szûrhetók le a nemzetközi összehasonlítást illetően a hatalmas kiterjedésư másodlagos irodalomból és néhány olyan indikátorból, amelyek fóként a beiskolázási arányokra és a $\mathrm{K}+\mathrm{F}$ célú felsőoktatási kiadásokra vonatkozóan állnak rendelkezésre (Mowery és Sampat, 2005).

A kutató egyetemek történelmileg először a 19. század közepén Poroszországban alakultak ki, egy olyan struktúrában, ami napjainkban „Humboldt-modellként” ismeretes, ma viszont úgy túnik, hogy az egyetemek mint alapkutatások végrehajtói jelentősebb helyet foglalnak el az Egyesült Államokban, mint bármely más iparosodott országban (Mowery és Rosenberg, 1993). Franciaországban például az olyan állami intézmények, mint a Tudományos Kutatások Országos Központja (CNRS), az Egészségügyi és Orvostudományi Kutatások Országos Intézete (INSERM) és a Pasteur Intézet ténylegesen központi szerepet játszanak mint alapkutatási intézmények. A német alapkutatás hasonlóképpen, fóként a Max Planck intézetekben koncentrálódik. Ezzel szemben az USA-ban a második világháború után - összhangban a nagy hatású Vannevar Bush-jelentéssel (1945) - az egyetemeket tekinterték az alapkutatások legmegfelelóbb intézményi bázisának. Ez a különbség - tekintettel az alapkutatás és az oktatási tevékenység erôs komplementaritására - szintén fontos lehet.

Másodszor, a hozzáférhetố adatok feltárják, hogy a magasabb arányú felsőfokú beiskolázás Amerikában nem új jelenség: az USA felsôoktatási intézményei a 20. század kezdete óta folyamatosan nagyobb hányadát fogadták be a megfelelố korcsoportnak, mint az európaiak (Modery és Sampat, 2005). ${ }^{15}$

Ez valószínúleg annak tulajdonítható, hogy az USA-ban éles megkülönböztetés áll fenn a tudományos kutatási fokozatokat adományozó egyetemi rangú felsőoktatási intézmények, a csak fớiskolai szintú (undergraduate) képzést nyújtó intézmények, illetve a múszaki fóiskolák között. Másrészt Európa (és különösen a kontinentális Európa) legtöbb egyetemén a fenti három képzési típus zavarba ejtő keverékével találkozunk. Anekdotikus bizonyítékok arra utalnak, hogy ez nem jó sem a kutatás, sem a tömeges képzés szempontjából.

Harmadszor, ha a felsőoktatási költségeket a beiratkozott diákok számára vetítve vizsgáljuk, az USA egyértelmúen jobb teljesítményt nyújt, mint az EU-országok.

\footnotetext{
${ }^{14}$ Az erre vonatkozó adatokat és azok elemzését lásd EC, 2003, 116.

${ }^{15}$ Figyelembe kell vennünk azonban, hogy a felsőoktatásban részt vevő hallgatók számában az egyes országok között mutatkozó különbségek a tanulmányi programok különbözó hosszúságából is adódhatnak.
} 


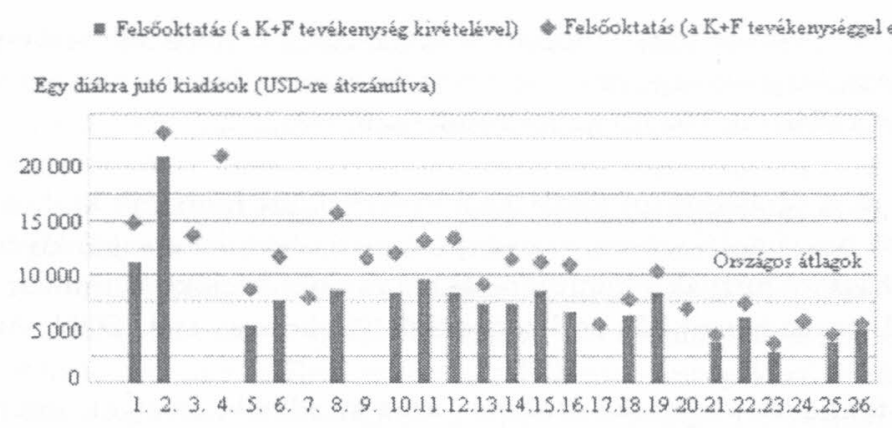

4. ábra. A felsóoktatásra fordított kiadások, egy beiratkozott hallgatóra vetítue

A vízszintes tengelyek szereplô országok: 1. Dánia 2. Egyesült Âllamok (1) 3. Norvégia 4. Svájc (2) 5. Olaszország (2) 6. Ausztria 7. Izland 8. Svédország 9. Japán 10. Belgium 11. Ausztrália 12. Hollandia 13. Franciaország (4) 14. Finnország 15. Egyesült Királyság 16. Németország 17. Portugália 18. Spanyolország 19. Írország 20. Korea (4) 21. Görögország 22. Magyarország (4) 23. Lengyelország $(2,4) 24$. Cseh Köztársaság 25. Mexikó (4) 26. Szlovák Köztársaság (SK)

(1) Csak állami és független magánintézmények.

(2) Csak állami intézmények.

(3) Az oszlop a felsôoktatásra fordított összes kiadást reprezentálja, a kutatási és fejlesztési költségek kivételével

(4) A felsőoktatásban a kutatásra és fejlesztésre fordított költségek, s így a K + F tevékenységet magában foglaló összesített költségek is alábecsültek.

Az országok az ábrán az elemi oktatásban egy tanulóra jutó kiadások csökkenô sorrendje szerint vannak feltüntetve.

Forrás: OECD, B11 és B6.2. táblázatok. További megjegyzések a 3. függelékben (www.oecd.org/edu/eag2004)

Negyedszer, az utóbbi években számos tudós hangsúlyozta az egyetemek szerepét az innovációs folyamatban, élesen szembeállítva azt az alapkutatások végzésében játszott szerepükkel. Ugyanakkor a döntéshozók a felsőoktatási intézményeket - az amerikai tapasztalatokat hangsúlyozva - egyre inkább stratégiai vagyonnak tekintik, amelyet mozgósítani kell, mégpedig az egyetemi kutatások eredményeinek hatékonyabb átvitelével az ipari szektorhoz. Az ilyen felfogást nagymértékben elősegítették a magas szintú technológia bizonyos regionális klasztereiról, különösen a Szilíciumvölgyról és a 128. számú országútról közkézen forgó sikertörténetek. Mindazonáltal először is kevés bizonyíték támasztja alá azt az érvet, hogy az egyetemek jelenléte önmagában regionális high-tech agglomerációk kialakulását eredményezi, továbbá semmiféle bizonyíték sem igazolja, hogy a szándékos állami stratégiai elófeszítések hatékonyak lennének ilyen agglomerációk létrehozásában. Másodszor, a Szilícium-völgyben elért sikerekról szóló részletes beszámolók inkább az 1945 utáni szövetségi honvédelmi kiadások erôteljes növekedésének fontosságát bizonyították meggyőző módon: a sikerekhez a vezetô egyetemek jelenléte szükséges, de nem elegendő feltételt jelentett (Saxenian, 1988). Mint Mowery és Sampat (2005, 19) helyesen megállapították:

„Az USA tapasztalatai arra utalnak, hogy az ilyen agglomerációk kialakulása véletlenszerú, az ott bejárt úttól és - ami a legfontosabb - más (szándékos 
vagy nem szándékolt) támogató politikai célok érvényesülésétól függ, amelyeknek kevés közük van az egyetemi kutatásokhoz vagy az egyetemek és az iparvállalatok közötti kapcsolatok ösztönzéséhez."

Végül, de nem utolsósorban részletes felmérések azt mutatták ki, hogy az USA ipari vállalatainak beszámolói szerint - a gyógyszeripari cégek lehetséges kivételével -a vállalatok több hasznot húznak a konferenciákból és publikációkból, mint az egyetemi prototípusokból, szabadalmakból és licencekból (Cohen és tsai, 2002; Arundel és Geuna, 2004).

Végül - a fentieket kiegészítő szinten - azok az adatok, amelyek arra mutatnak, hogy az egyetemek és az ipar közötti kapcsolatok az USA-ban erôsebbek, mint Európában, legalábbis vegyesek: ha az egyik oldalon a munkaerô mobilitását tükröző kvalitatív adatok bizonyos mértékig ezt az elterjedt meggyôződést támasztják is alá, a másik oldalon a felsôoktatási $\mathrm{K}+\mathrm{F}$ ipari támogatására vonatkozóan fent bemutatott adatok éppen ennek az ellenkezójére mutatnak.

\subsection{Múszaki tevékenység}

A nemzetek múszaki teljesítményének (technological Output of Nations) megvilágítására az innovációra irányuló kutatási erốfeszítések intenzitásának és az ezekben részt vevő munkaerő képességeinek mérésére alkalmazott különféle megközelítések mellett általában a szabadalomalapú indikátorokat használják. A múszaki teljesítménynek valószínúleg a szabadalomalapú indikátorok a leggyakrabban alkalmazott mércéi; az ilyen indikátorok kiszámítására azonban nincs általánosan elfogadott, standard módszer, ami ahhoz vezet, hogy a szabadalmi statisztikákból leszúrhetố politikai/stratégiai tanulságok gyakran meglehetôsen divergensek (Dernis és Guellec, 2001). Észben kell tartani továbbá ennek a módszernek néhány hátrányát. Elốször is, az intézmények közötti különbségek, továbbá az eltérố vállalati elsajátítási stratégiák és az egyes szektorok más-más szabadalomképzési hajlamai is eltorzíthatják a nemzetközi összehasonlításokat. Másodszor, a szabadalmak értékmegoszlása erốsen torz, sok szabadalomnak egyáltalán nincs ipari alkalmazása. A nagymértékủ heterogeneitás azt vonja maga után, hogy ha nem teszünk különbséget az eltérő értékú szabadalmak között, akkor nem nagy információs értékú indikátorokhoz jutunk. Harmadszor, a szabadalmi törvények változásai megnehezítik a hosszú távon érvényesülő trendek elemzését. Különösen a szabadalmak birtokosainak nyújtott védelem növekedett meg világszerte az 1980-as évek eleje óta (elsôsorban az USA-ban), ${ }^{16}$ továbbá a szabadalomképes múszaki megoldások száma is jelentősen kibővült. Végül, de nem utolsósorban a szabadalomalapú indikátorokat általában az országos szabadalmi hivatalok által közölt alkalmazási jegyzékek alapján szerkesztik meg, amelyek többnyire elfogultak a saját országuk iránt.

A következókben a fenti korlátok tudomásulvételével összehasonlítjuk azoknak a szabadalmaknak a részarányait, amelyeket a különféle szabadalmi hivatalokban beje-

\footnotetext{
${ }^{16}$ Az európai döntéshozók túlságosan gyakran követendő modellnek tekintik az USA szabadalmi rendszerét, melynek fogyatékosságait lényegretörôen írja le Jaffe és Lerner, 2004.
} 
gyeztek, azok benyújtóinak lakóhelye és elsóbbségi dátumai szerint: ${ }^{17}$ az OECD kifejlesztett olyan „szabadalomcsaládokat” (vagyis ugyanannak a találmánynak a védelmére különböző országokban bejegyzett szabadalmakat), amelyek megpróbálják enyhíteni az „itthoniak előnyben” jelszóban összegezhetố elfogultságot, és általában megragadják a viszonylag magas gazdasági értékú szabadalmakat. Ennek az az árnyoldala, hogy a triadikus szabadalmak birtokosai rendszerint a nagyvállalatok, s ennélfogva a kisebb vállalatoknál folyó innovációs tevékenységet valószínúleg alábecsülik. ${ }^{18}$

A 10. táblázat bemutatja az EU-25 és az USA részarányát a „triadikus” szabadalomcsaládokban. Azokat a találmányokat sorolják ide, amelyek az Európai Szabadalmi Hivatalnál (European Patent Office, EPO), a Japán Szabadalmi Hivatalnál (Japanese Patent Office, JPO) és az USA Szabadalmi és Védjegy- Hivatalánál (US Patent and Trademark Office, USPTO) vannak bejegyezve. Ezek a részarányok viszonylag stabilak, az európai részesedés enyhe mértékű csökkenése mellett.

10. táblázat. Részesedés a „triadikus” szabadalomcsaládokból

\begin{tabular}{|c|c|c|c|c|c|c|}
\hline & 1990 & 1992 & 1994 & 1996 & 1998 & 2000 \\
\hline & \multicolumn{6}{|c|}{ Valamennyi terület } \\
\hline EU-25 & 0,27 & 0,28 & 0,29 & 0,29 & 0,30 & 0,23 \\
\hline \multirow[t]{2}{*}{ US } & 0,39 & 0,40 & 0,40 & 0,38 & 0,36 & 0,38 \\
\hline & \multicolumn{6}{|c|}{ Ürkutatás } \\
\hline EU-25 & 0,17 & 0,18 & 0,21 & 0,21 & 0,23 & 0,20 \\
\hline \multirow[t]{2}{*}{ US } & 0,40 & 0,43 & 0,44 & 0,41 & 0,39 & 0,39 \\
\hline & \multicolumn{6}{|c|}{ Gépészmérnökség/gépipar } \\
\hline EU-25 & 0,41 & 0,39 & 0,39 & 0,40 & 0,41 & 0,30 \\
\hline \multirow[t]{2}{*}{ US } & 0,30 & 0,34 & 0,27 & 0,23 & 0,23 & 0,26 \\
\hline & \multicolumn{6}{|c|}{ Vegyipar/kémia } \\
\hline EU-25 & 0,33 & 0,36 & 0,36 & 0,34 & 0,34 & 0,28 \\
\hline \multirow[t]{2}{*}{ US } & 0,42 & 0,40 & 0,39 & 0,41 & 0,40 & 0,45 \\
\hline & \multicolumn{6}{|c|}{ Anyagmérnökség/anyagtudomány } \\
\hline EU-25 & 0,29 & 0,33 & 0,31 & 0,31 & 0,32 & 0,21 \\
\hline \multirow[t]{2}{*}{ US } & 0,37 & 0,35 & 0,34 & 0,33 & 0,33 & 0,38 \\
\hline & \multicolumn{6}{|c|}{ Biotechnológia } \\
\hline EU-25 & 0,29 & 0,30 & 0,29 & 0,26 & 0,26 & 0,19 \\
\hline \multirow[t]{2}{*}{ US } & 0,50 & 0,47 & 0,50 & 0,53 & 0,55 & 0,62 \\
\hline & \multicolumn{6}{|c|}{ IKT-szektor } \\
\hline EU-25 & 0,17 & 0,18 & 0,21 & 0,21 & 0,23 & 0,20 \\
\hline US & 0,40 & 0,43 & 0,44 & 0,41 & 0,39 & 0,39 \\
\hline
\end{tabular}

${ }^{17}$ A szabadalom benyújtója alatt ebben az esetben azt a személyt érjük, aki a benyújtás idôpontjában a szabadalmat birtokolja. Ez az osztályozás a tulajdonjogra koncentrál, és attól függetlenül tükrözi az adott ország innovatív teljesítményét, hogy a kutatási környezet, amelyben az adott szabadalmat kifejlesztették, hol helyezkedik el. Az elsôbbségi dátum a szabadalom első benyújtásának idôpontja a világ bármely országában, és a legközelebb esik (a szabadalomért való folyamodáshoz és a szabadalom megítéléséhez képest) a feltalálás idôpontjához.

${ }^{18}$ Bôvebben lásd Dernis és Khan, 2004. 


\begin{tabular}{|l|c|c|c|c|c|c|}
\hline & 1990 & 1992 & 1994 & 1996 & 1998 & 2000 \\
\hline & 0,22 & 0,26 & 0,28 & 0,27 & 0,30 & 0,21 \\
\hline EU-25 & 0,42 & 0,46 & 0,45 & 0,43 & 0,39 & 0,47 \\
\hline US & \multicolumn{7}{|c|}{ Távközlés } & & \\
\hline \multicolumn{7}{|c|}{ Fogyasztói elektronika } \\
\hline EU-25 & 0,10 & 0,11 & 0,11 & 0,14 & 0,15 & 0,22 \\
\hline US & 0,30 & 0,34 & 0,41 & 0,35 & 0,35 & 0,26 \\
\hline EU-25 & 0,11 & 0,13 & 0,16 & 0,15 & 0,18 & 0,17 \\
\hline US & 0,45 & 0,46 & 0,46 & 0,43 & 0,42 & 0,39 \\
\hline
\end{tabular}

Megjegyzés: a triadikus szabadalomcsaládokba azok a találmányok tartoznak, amelyeket az Európai Szabadalmi Hivatalnál (European Patent Office, EPO), a Japán Szabadalmi Hivatalnál (Japanese Patent Office, JPO) és az USA Szabadalmi és Védjegy Hivatalánál (US Patent and Trademark Office, USPTO) bejegyeztek. A módszertani részleteket illetôen lásd Dermis és Khan (2004).

Forrás: OECD online adatbázis.

Az európai teljesítmény azonban jelentôs változatosságot mutat a különféle múszaki területeken. A 10. táblázat alsó része az USA és az EU szabadalmak részarányát tükrözi 9 fố területen. A táblázat az ưrkutatási, gépészmérnöki, vegyészmérnöki és anyagmérnöki találmányokat a nemzetközi szabadalmi osztályozás (International Patent Classification) szerint tünteti fel, míg a biotechnológia, valamint az IKT és annak három alosztálya terén az osztályozás különféle technológiai alterületek összevonásával történt, az OECD által javasolt módszernek megfelelóen. ${ }^{19}$ Látható, hogy az EU viszonylag erōs a gépészmérnöki és anyagmérnöki teljesítmény tekintetében (még akkor is, ha az utóbbi három évben erốs hanyatlás tapasztalható), és ugyanakkor gyengeséget mutat a biotechnológia területén. Az úrkutatási és vegyészmérnöki teljesítmények közelebb állnak a „valamennyi területre” vonatkozó részarányokhoz. Meglehetôsen érdekes képet kapunk, ha az IKT részarányait három különböző alcsoportra bontjuk fel. A fogyasztói elektronika területén - elsósorban a skandináv országok teljesítményének következtében - világosan látható a felzárkózás, ${ }^{20}$ míg a számítógépek, az irodafelszerelések és a távközlés területén az Európai Unió országai még mindig lemaradásban vannak.

Az EU és az USA közötti szakadék részben a különbözó (vállalati és egyetemi/felsốoktatási) szervezeti rendszereknek a szabadalmaztatásra való eltérố hajlamosságából is adódik, amit egyúttal a különböző szabadalmi rendszerek is erôsítenek. A divergens trendek és az egyes alterületeken mutatkozó különbségek (amelyek viszont többnyire különböző $K+F$ erófeszítéseket tükröznek) ténylegesen rámutatnak Európa valódi gyöngeségeire az innováció terén.

Egy utolsó megjegyzésünk a szabadalmak fontosságára vonatkozik, nem csupán az innovációs teljesítmény megközelítô mércéjének, hanem egyben olyan gazdasági intézménynek is tekintve azokat, ami innovációt és jólétet teremt. A standard gazdasági elmélet szerint az optimális szabadalmazási mechanizmusnak ki kellene egyensúlyoz-

${ }^{19}$ Az ehhez használt módszerek részletes leírása megtalálható az alábbi honlapon http://www1.oecd.org/scripts/cde/members/patentFamiliesAuthenticate.asp

${ }^{20}$ A tovább bontott adatok a szerzóknél kívánságra rendelkezésre állnak. 
nia a monopóliumok bérleményeiból fakadó statikus veszteségeket azokkal a dinamikus társadalmi nyereségekkel, amelyek a nagyobb innovációs erő́feszítésból származnak. Az utóbbi hatásra vonatkozóan azonban meglepoóen kevés bizonyíték lelhetô fel. ${ }^{21}$ A másik oldalon, még a gyógyszeriparban, vagyis abban az ipari szektorban is, ahol a szabadalmak valóban az innovációk alapvető védelmi eszközét jelentik a hamisítók ellen, a termékek szabadalmi védelmének hiánya gyakran az innováció hirtelen elterjedéséhez és - kevésbé spontán módon - az illetô tudás adásvételéhez vezetett, ami hozzájárult az adott technológiai megoldások túlságosan korai piacra kerüléséhez (Dosi és tsai, 2005).

Összefoglalva: a K + F-re fordított költségek és a szabadalomalapú indikátorok Európa lemaradását mutatják mind az alacsonyabb kutatási befektetések, mind az alacsonyabb innovációs teljesitmény tekintetében. Ez nagymértékben az olyan múszaki területeken való gyengeség következménye, amelyeket általában a mai „tudásgazdaság” motorjának tekintenek. Másrészt bizonyos adatok Európa erôsségét mutatják a gépészmérnöki és anyagmérnöki technológiák terén.

\section{Az európai gazdaság és az európai vállalatok strukturális gyengeségei}

Ebben a fejezetben azokat a korlátokat és gyengeségeket vizsgáljuk meg, amelyek az európai gazdasági vállalkozásokat jellemzik az innováció és a világgazdaságban való versengés területén. Az adatok nézetünk szerint azt jelzik, hogy az európai vállalatok rosszabbodó teljesítménye mögött meghúzódó alapvetố tényezố nem más, mint a vállalatok kisebb elkötelezettsége a kutatás és a nemzetközi szabadalmaztatás iránt, továbbá egyes szektorokban a vállalatok alacsony szintú részvétele a központi nemzetközi oligopóliumokban. Másrészt viszont, mint fentebb jeleztük, nem találtunk semmiféle bizonyítékot ${ }^{22}$ arra a gyakran emlegetett gyengeségre, ami a gazdaság és az egyetemek közötti kapcsolatok tekintetében Európát hátrányos helyzetben mutatja az USA-hoz képest (lásd például 3. ábra és 6. táblázat).

Az alábbiakban elsósorban azokra az iparágakra koncentrálunk, ahol Európa tudományos és múszaki innovációs lemaradásának következményei valószínúleg súlyosabbak.

Az 5. ábra a termelés megoszlását mutatja különféle IKT-szektorokban. Amikor az EU-15 és az USA általános helyezési mutatói a rangsorban többé-kevésbé stabilak maradnak, akkor a részesedési arányok azt mutatják, hogy az EU - összhangban a szabadalmazási teljesítmény adataival - elvesztette vezetố szerepét még a távközlési iparban is, ahol a 90-es években még nagy elônyben volt. Európa teljesítménye hanyatlott az Egyesült Államokéhoz képest az irodatechnikai berendezések terén is. Másrészt a rádiófrekvenciás kommunikáció és a radar-berendezések területén az Egyesült Államok elônye valamelyest csökkent Európához képest (ez viszont valószínúleg néhány új európai vállalat létrejöttének az eredménye, különösen a honvédelmi szektorban, melyeknek a mérete és kapacitása legalábbis összehasonlítható amerikai partnereikével).

\footnotetext{
${ }^{21}$ Lásd például Sakakibara és Branstatter, 2001.

${ }^{22}$ Azzal a lehetséges kivétellel, hogy az európai vállalatok kevésbé hajlamosak jól képzett kutatókat toborozni.
} 

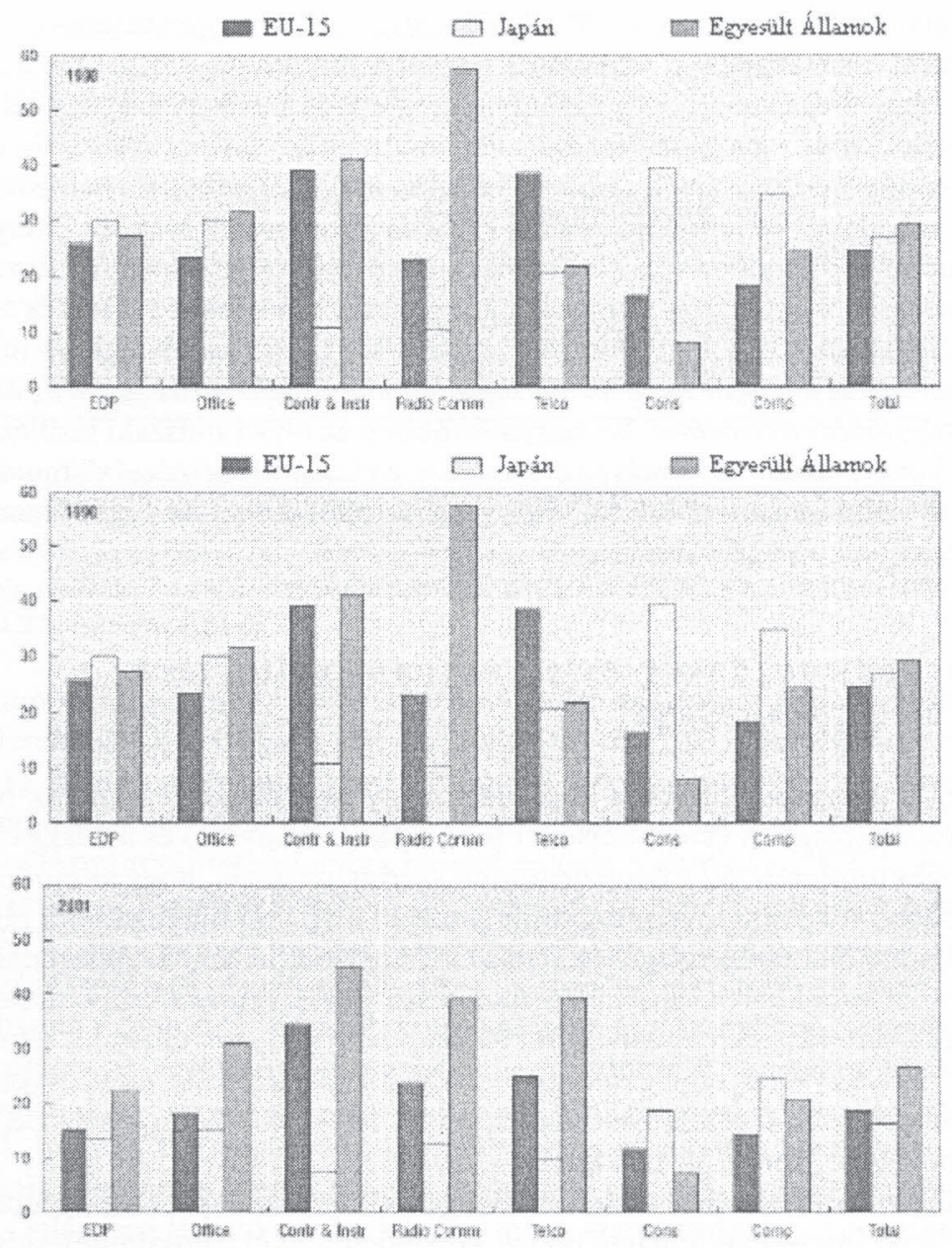

5. ábra. A világ IKT-termelésének megoszlása

Százalékos részesedés szektoronként (USD, 2005) ${ }^{23}$

Megjegyzés: A részesedési arányok a 2005. évi USD-árfolyamokon vannak megadva, tehát az árfolyamváltozások (erős USD 2000-2001-ben) rövid távon nagy hatást gyakorolnak az IKT-termelésben való részesedés viszonylagos arányainak kiszámítására. 1990-ból nem voltak elérhetô adatok Görögországra, Luxemburgra és Portugáliára nézve. A másik két évre nézve Luxemburgra vonatkozóan nem álltak rendelkezésre adatok.

Forrás: Reed Elektronikai Kutatóintézet (Reed Electronics Research), különféle évek. Ismételt közlés: OECD, 2004b.

${ }^{23}$ A táblázatok vízszintes tengelyén szereplő rövidítések: EDP: elektronikus adatfeldolgozás (Electronic Data Processing), Office: irodatechnika, Contr \& Instr: vezérlóberendezések és múszerek (Control and Instrumentation), Radio Comm: rádiófrekvenciás kommunikáció (beleértve a mobiltelefóniát) és radar, Telco: távközlés (Telecommunications), Cons: fogyasztói audio- és videoelektronika (Consumer audio and video), Comp: alkatrészek és részegységek (Components), Total: összes. 
Hasonló eredményekre jutunk az IKT-ra (irodagépekre, adatfeldolgozó berendezésekre, adatkommunikációs és telekommunikációs berendezésekre, továbbá ezekhez kapcsolódó szoftverekre és távközlési szolgáltatásokra) fordított költségek összehasonlítása terén is, azokat a GDP százalékában kifejezố adatokat vizsgálva. A 11. táblázat azt mutatja, hogy valamennyi európai ország - Svédország és az Egyesült Királyság figyelemre méltó kivételével - kevesebbet invesztál ezen a téren, mint az USA.

11. táblázat. Az IKT-ra fordított költségek a GDP százalékában

\begin{tabular}{|l|c|c|c|c|}
\hline \multicolumn{1}{|c|}{ Ország } & $\mathbf{2 0 0 1}$ & $\mathbf{2 0 0 2}$ & $\mathbf{2 0 0 3}$ & $\mathbf{2 0 0 4}$ \\
\hline Finnország & 6,6 & 7,1 & 7,0 & 7,1 \\
\hline Franciaország & 6,1 & 6,2 & 5,9 & 6,0 \\
\hline Németország & 6,3 & 6,1 & 6,0 & 6,2 \\
\hline Olaszország & 5,2 & 5,4 & 5,3 & 5,3 \\
\hline Spanyolország & 5,2 & 5,6 & 5,4 & 5,2 \\
\hline Svédország & 8,5 & 9,2 & 8,8 & 8,7 \\
\hline Egyesült Királyság & 7,4 & 8,6 & 8,8 & 7,9 \\
\hline EU-15 & 6,3 & 6,6 & 6,4 & 6,3 \\
\hline EU-25 & 5,6 & - & - & 6,4 \\
\hline USA & 8,6 & 8,1 & 7,9 & 7,8 \\
\hline
\end{tabular}

Forrás: EIS, 2005

Bizonyos mértékig hasonló képet kapunk a fóbb high-tech szektorok kereskedelmi adatainak mérése útján is. A 12. táblázat néhány kiválasztott EU-tagországnak az exportpiacból való részesedését mutatja, figyelmen kívül hagyva az Európai Unión belülre irányuló szállításokat. Míg az ûrkutatás részesedése az USA-ban valamelyest visszaesett, miközben az EU-ban növekedett, ennek az ellenkezője történt a múszeripar és a gyógyszeripar területén.

12. táblázat. Külkereskedelem a high-tech iparágakban: exportpiaci részesedések az OECD országok összes exportjának százalékában (az Európai Unión belïlre irányuló export kivételével)

\begin{tabular}{|l|c|c|c|c|c|c||}
\hline & 1996 & 1997 & 1998 & 1999 & 2000 & 2001 \\
\hline \hline & \multicolumn{7}{|c|}{ Ürkutatás } \\
\hline Franciaország & 0,12 & 0,09 & 0,10 & 0,12 & 0,12 & 0,11 \\
\hline Németország & 0,06 & 0,06 & 0,06 & 0,06 & 0,07 & 0,10 \\
\hline Olaszország & 0,02 & 0,02 & 0,02 & 0,02 & 0,02 & 0,02 \\
\hline Egyesült Királyság & 0,05 & 0,11 & 0,10 & 0,10 & 0,10 & 0,10 \\
\hline Egyesült Államok & 0,54 & 0,52 & 0,52 & 0,52 & 0,48 & 0,45 \\
\hline & \multicolumn{7}{|c|}{ Elektronika } \\
\hline Franciaország & 0,02 & 0,02 & 0,02 & 0,02 & 0,02 & 0,02 \\
\hline Németország & 0,04 & 0,04 & 0,04 & 0,04 & 0,04 & 0,05 \\
\hline Olaszország & 0,01 & 0,01 & 0,01 & 0,01 & 0,01 & 0,01 \\
\hline Egyesült Királyság & 0,03 & 0,03 & 0,03 & 0,03 & 0,03 & 0,03 \\
\hline Egyesült Államok & 0,03 & 0,31 & 0,36 & 0,36 & 0,36 & 0,36 \\
\hline
\end{tabular}




\begin{tabular}{|l|c|c|c|c|c|c|c||}
\hline & 1996 & 1997 & 1998 & 1999 & 2000 & 2001 \\
\hline \hline & \multicolumn{7}{|c|}{ Irodatechnika és számítógépek } \\
\hline Franciaország & 0,01 & 0,02 & 0,01 & 0,01 & 0,01 & 0,01 \\
\hline Németország & 0,03 & 0,03 & 0,04 & 0,04 & 0,03 & 0,03 \\
\hline Olaszország & 0,01 & 0,01 & 0,01 & 0,01 & 0,01 & 0,01 \\
\hline Egyesült Királyság & 0,06 & 0,05 & 0,05 & 0,04 & 0,04 & 0,05 \\
\hline Egyesült Államok & 0,36 & 0,35 & 0,38 & 0,37 & 0,37 & 0,38 \\
\hline & 0,05 & 0,05 & 0,04 & 0,05 & 0,05 & 0,06 \\
\hline Franciaország & 0,13 & 0,15 & 0,16 & 0,15 & 0,13 & 0,13 \\
\hline Németország & 0,13 & 0,04 & 0,04 & 0,05 & 0,04 \\
\hline Olaszország & 0,05 & 0,04 & 0,07 & 0,07 & 0,08 & 0,07 \\
\hline Egyesült Királyság & 0,08 & 0,08 & 0,21 & 0,21 & 0,24 & 0,24 \\
\hline Egyesült Államok & 0,21 & 0,22 & Múszeripar & \\
\hline & 0,03 & 0,03 & 0,02 & 0,03 \\
\hline Franciaország & 0,03 & 0,03 & 0,03 & 0,10 & 0,09 & 0,08 & 0,09 \\
\hline Németország & 0,10 & 0,10 & 0,10 & 0,02 & 0,02 \\
\hline Olaszország & 0,02 & 0,02 & 0,02 & 0,02 & 0,05 \\
\hline Egyesült Királyság & 0,05 & 0,05 & 0,05 & 0,05 & 0,05 & 0,05 \\
\hline Egyesült Államok & 0,35 & 0,37 & 0,38 & 0,38 & 0,39 & 0,39 \\
\hline
\end{tabular}

Megjegyzés: Az adatok számítása a STAN-adatbázison alapul. Az OECD-országok adatai nem tartalmazzák a Cseh Köztársaság, Magyarország és Korea adatait. Az ISIC-osztályozásban (ISIC revision 3) az itt szereplố iparágak az alábbi jelzetekkel szerepelnek: úrkutatási iparágak (353); elektronikai iparágak, ISIC (32); irodatechnika és számítógépipar (30); gyógyszeripar (2423); orvosi, precíziós és optikai műszerek, óragyártás és időmérô múszerek iparágai (33).

Az OECD 2004. évi információs technológiai áttekintése (Information Technology Outlook) különféle források kombinációjával vizsgálja meg a legnagyobb 250 IKT-vállalat, valamint 4 alszektorban (kommunikációs berendezések és rendszerek, elektronikai berendezések részegységei, IT-berendezések és rendszerek, IT-szolgáltatások, szoftver és távközlés) a 10 legnagyobb vállalat teljesítményét (OECD, 2004b). Ebból kiviláglik, hogy a legnagyobb 250 cég közül 139 (56\%) az Egyesült Államokban van, míg csupán $33(13 \%)$ az Európai Unióban - ez megerôsíti az EU általános gyengeségét a világ iparának vezetói körében, bizonyos szubszektorális kivételekkel. Így hat európai vállalat található a tíz legnagyobb telekommunikációs szolgáltató vállalat között, három a kommunikációs berendezéseket és rendszereket gyártó cégek hasonló csoportjában, kettố a tíz legnagyobb elektronikai berendezéseket és azok részegységeit gyártó vállalatok között, és csupán egy a tíz legnagyobb szoftvercég között. Végül, egyáltalán nincsenek európai cégek az IT-berendezéseket és rendszereket gyártó tíz legnagyobb vállalat között.

Másrészt, ha az olyan érettebb iparágakat vesszük szemügyre, mint például a gép- és szerszámipar, akkor az európai országok egy válogatott csoportjának tartós vezető szerepét látjuk. Mint a 13. ábra mutatja, ezeknek az iparágaknak a teljes termelési volumenét tekintve mind Németország, mind Olaszország felülmúlja az Egyesült Államokat. 
13. táblázat. A szerszámgépipari termelés (millió euró, 2005)

\begin{tabular}{|l|r|r|r|r|r|r|r|r|r||}
\hline & 1995 & 1996 & 1997 & 1998 & 1999 & 2000 & 2001 & 2002 & 2003 \\
\hline Németország & 5556 & 5956 & 5986 & 6686 & 7157 & 7538 & 8629 & 7427 & 6660 \\
\hline Olaszország & 2541 & 2966 & 3041 & 3258 & 3519 & 4163 & 4240 & 4007 & 3678 \\
\hline Egyesült Államok & 3416 & 3563 & 4325 & 4216 & 3460 & 3836 & 3185 & 2440 & 1954 \\
\hline Spanyolország & 506 & 632 & 719 & 844 & 910 & 929 & 990 & 911 & 836 \\
\hline Franciaország & 738 & 652 & 642 & 703 & 742 & 912 & 908 & 746 & 673 \\
\hline
\end{tabular}

Forrás: A táblázatban szereplố adatokat az UCIMU (az olasz szerszámgép-, robot- és automatagyártók egyesülete) dolgozta ki az amerikai gépészeti társaság adatai alapján.

Továbbá, mint a 14. táblázat mutatja, ezeknek az országoknak a vezetô szerepe a világ exportjából való nagyobb részesedésükból következik. Úgy véljük, hogy a fenti eredmények egybecsengenek az európai országok erôsségének megállapításával azokon a tudományos és múszaki területeken, amelyek szorosabban összefüggenek a szerszámgépiparral (alkalmazott fizika és gépészmérnöki tudományok).

14. táblázat. Részesedések (\%) a világ exportjából a szerszámgépiparban

\begin{tabular}{|l|c|c|}
\hline & $\mathbf{2 0 0 1}$ & $\mathbf{2 0 0 2}$ \\
\hline Németország & 20,67 & 23,52 \\
\hline Olaszország & 9,50 & 10,05 \\
\hline Egyesült Államok & 5,06 & 4,52 \\
\hline Spanyolország & 2,27 & 2,89 \\
\hline Franciaország & 2,78 & 2,53 \\
\hline
\end{tabular}

Forrás: A táblázatot a szerzók dolgozták ki az UCIMU (az olasz szerszámgép-, robot- és automatagyártók egyesülete) adatai alapján.

A fenti adatok egy része alátámasztja azt a feltételezést, hogy a high-tech szektorokban - a tudományos kutatás és az ipari alkalmazások közötti „,hidaktól” függetlenül - az európai nagyvállalatok potenciális részesedése kisebb, gyengébb és kevésbé rugalmas, mint az óceánon túli partnereiké.

Ezt jól aláhúzzák azok a feltáró erejû́ esetek is, amelyeknél a tudomány teljesítménye eléri a világklasszis mércéjét, valamennyi „transzfermechanizmus” a helyén van, ám az eredményekból mégis alig húznak hasznot az európai vállalatok. Ennek egyik kirívó példáját adják az angliai Cambridge-ben születô számítógép-tudományi eredmények: ezt a kiváló tudományos teljesítményt leginkább nem európai vállalatok (a Fujitsutól a Microsoftig, és sokan mások) aknázzák ki. 


\title{
6. Konklúzió, néhány szerény javaslattal, a melyek segíthetik az európai innovácios teljesitmény javítását
}

Összefoglalva: az európai helyzetkép minden bizonnyal tarka, mind a tudományos tudás, mind a múszaki innováció tekintetében. A jelentős gyengeségek azonban a tudományos kutatások európai rendszerében és a viszonylag gyengébb európai ipari potenciálban rejlenek. Az utóbbit - mint kimutattuk - általában az új technológiai paradigmák (például az IKT és a biotechnológiák) terén tapasztalható viszonylag alacsonyabb szintú jelenlét, az innováció iránti csekélyebb ösztönzés, valamint számos tevékenységben a nemzetközi oligopóliumokban való viszonylag gyenge részvétel jellemzi.

Az EU-országok között kétségkívül vannak komolyabb eltérések, ám ugyanez elmondható az USA államairól is. ${ }^{24} \mathrm{Az}$ Európai Unió esetében további gondok adódnak a munkaerô kisebb mobilitásából, az intézmények sokféleségéból, valamint a tagországok közötti nyelvi határokból. Mindezek a tényezók problematikusabbá teszik a konvergencia megvalósulását.

Ez a helyzet erôs tudománypolitikát és iparpolitikát tesz szükségessé. Mindazonáltal eddig ennek majdnem pontosan az ellenkezôje volt tapasztalható a valóságban. A kutatás „hasznosságára” helyezett hangsúly egy olyan politikai csomag kialakításához vezetett, melynek jegyében - különösen az úgynevezett „,keretprogramok” (Framework Programmes) létrehozása óta - az EU-ban lényegében nem létezik az alapkutatások támogatása.

\begin{abstract}
„A lehetséges gyakorlati és tudományos hasznok meghatározására kutatásiprogramjavaslatokat várnak el; magasabb prioritást kap a felhasználók bevonása a kutatásokba (beleértve a részleges finanszírozást), az egyetemeket arra ösztönzik, hogy több jövedelmet húzzanak intellektuális tulajdonaik licenceinek áruba bocsátásából, és lényeges központi állami alapokat költöttek el olyan ,jövóbe tekintô” (foresight) programokra, amelyeket az alkalmazások jövóbeli lehetôségeivel kapcsolatos eszmecserék során kialakítandó konszenzus elérése érdekében hoztak létre” (Pavitt, 2001, 268).
\end{abstract}

Az ipari K + F tekintetében a „versengés elôtti” (pre-competitive) kutatásra helyezett hangsúly hasonlóképpen egyfajta sajátos imaginárius dimenzió kialakulását eredményezte, ahol a vállalatok - gyakran a tudósokkal szövetkezve - megpróbálják megcsapolni az állami pénzeket olyan területeken, amelyek eléggé marginálisak ahhoz, hogy ne legyen érdemes odainvesztálniuk a saját pénzüket. Továbbá a hálózatépítési hullám kéz a kézben járt a tudományos kutatási bürokraták számának és hatalmának növekedésével (mind összeurópai szinten, mind az országos szinteken).

Ha a diagnózisunk helyes, akkor ez a helyzet rossz a kutatás számára, pazarló a társadalomnak, és rossz a gazdaság számára is. A fenti elemzésból levonható az alábbi néhány következtetés:

${ }^{24}$ Ennél a pontnál hangsúlyozni kívánjuk, hogy az USA egyes államainak szintjére vonatkozó indikátorokat nehéz összehasonlítani az EU-országok hasonló indikátoraival, mivel az elóbbiek más-más fiskális ösztönzók meglétéból következố problémákat tükröznek (például Delaware állam statisztikáit eltorzítja az a tény, hogy igen sok amerikai vállalat jogilag ebben az államban van bejegyezve). 
Elôször is, növelni kell a magas szintü tudományos alapkutatások támogatását, olyan agilis intézményeken keresztül, amelyek világszínvonalú tudóstársi értékelésekre támaszkodnak, fizikailag lehetóleg Brüsszeltól minél távolabb helyezkednek el, és sokban hasonlítanak az amerikai Országos Tudományos Alapítványra (National Science Foundation, NSF). Ebben az irányban az Európai Tudományos Tanács (European Science Council) létrehozása 2004 májusában örvendetes fejlemény volt.

Másodszor, teljes mértékben tudomásul kell venni a különbségeket a felsöoktatási intézmények között, amelyek elválasztják egymástól (i) a posztgraduális képzést nyújtó kutató egyetemeket, (ii) a mesterfokozatot nem nyújtó oktató egyetemeket és (iii) a múszaki fóiskolákat.

Az elsố típushoz tartozó intézmények szerepére helyezett hangsúlyt gyakran az úgynevezett „Humboldt-modellként” említik, melynek úttörője több mint egy évszázaddal ezelốt Németország volt. Ma azonban ez a gyakorlat fóleg Amerikára jellemzó, míg Európa (különösen a kontinentális Európa) legtöbb egyeteme gyakran mindezeknek a funkcióknak a zavaros keverékét nyújtja, ami nem jó sem a kutatás, sem a tömeges képzés számára.

Harmadszor, a kutatási eredmények nyilvánossága érdekében vissza kell szoritani az államilag finanszírozott kutatások növekvố kisajátítása irányában ható tendenciákat.

Gyakran megfeledkezünk arról, hogy a kisajátíthatóság társadalmilag csak annyiban igazolható, amennyiben az maga is ösztönzóként hat az innovációra. Mint fentebb kifejtettük, az állami kutatások eredményeinek kisajátítása nem tölti be ezt a szerepet. Ez természetesen elsôsorban az alapkutatásokra vonatkozik, míg a kép sokkal homályosabb az olyan gyakorlatra orientált ágazatokban, mint a múszaki tudományok, illetve a mérnöki tevékenység. Ennélfogva nagyfokú pragmatizmusra van szükség. Mindazonáltal azt az általános álláspontot tesszük magunkévá, hogy a kisajátíthatóságra és az $I P R$-re helyezett túlságosan nagy hangsúly valószínúleg ártalmas hatást gyakorol a kutatásoknak mind a mértékére, mind az irányaira, továbbá jelentốs gátló tényezốt jelenthet a gazdasági érdekek által ösztönzött innováció terén is.

Az USA-hoz képest mutatkozó lemaradásunk az olyan intézményi változások terén, amelyek sokkal inkább tulajdonalapú kutatási rendszer kialakulásához vezetnek, ebben az esetben elốnyös is lehet annyiban, hogy számunkra könnyebb lehet megállítani ezt a folyamatot, és megfordítani a tendenciát (a kisajátíthatósággal összefüggésben fent jelzett álláspontunk részletes kifejtését illetően lásd Nelson, 2004).

Negyedszer: ambiciózus, technológiailag merész vállalkozások létrehozására van sะükség, amelyek a bennïk rejló társadalmi és politikai érték alapján igazolhatók.

Mint Pavitt (2001) emlékeztet rá bennünket, „,a skandináv országok és Svájc képesek jelentôs forrásokat mozgósítani magas szintú alapkutatásaikra, a világ egyetlen szuperhatalmának óriási honvédelmi és egészségügyi kiadásai nélkül”: ebból kiindulva Pavitt azt állítja, hogy „, a nagyobb európai országoknak és magának az Európai Uniónak is többet kell tanulnia ezektól az országoktól, mint az USA-tól (776. oldal).

Mindezeknek a megállapítása mellett sem szabad azonban kétségbe vonni a nagy léptékú és nagy kihatású európai programok fontosságát, amelyek ambiciózus és technológiailag kihívást jelentő célokat túznek ki például az energiatakarékosság, az egészségügy és a környezetvédelem terén (és talán még az európai újrafelfegyverkezés terén is, bár erról nemigen van egyetértés, még ennek a tanulmánynak a szerzói között sem!). 
Ötödször: újra fel kell fedezni az iparpolitika mint az erósebb és innovativabb európai ipar elömozditására szolgáló eszköz felhasználási lehetóségeit.

Teljes mértékben tudatában vagyunk annak, hogy ma az „iparpolitika” rossz csengésû́ szó, amelyet jobb társaságban nem lehet kiejteni anélkül, hogy az embert meggyanúsítanák azzal, hogy az ôsrégi kövületnek számító „nemzeti bajnokok” érvényesülését támogatja, ami eltorzítja a versenyt, és az olyan termelési minták terjedését propagálja, amelyek ellenkeznek a „feltárt” viszonylagos előnyökkel stb. Kísértést érzünk rá, hogy azt mondjuk: „Miért ne?”! A 70-es évek végéig, illetve a 80-as évek elejéig tartó időszakban, amit a politikai döntéshozóknak a különféle iparágak alapvetố struktúrájába való önkényes beavatkozásai jellemeztek, minden bizonnyal sok hiba történt, de volt számos siker is. Például Európa erôssége a távközlésben, markáns jelenléte a félvezetốk területén, növekvố versenyképessége a repülőgépgyártás terén stb. szintén az ,intervencionista” korszak politikai intézkedéseinek az eredményei. Úgy gondoljuk, hogy ma - még az új kereskedelmi egyezmények korlátai között is - sokkal többet lehetne tenni az európai jelenlét erősítése céljából a legígéretesebb technológiai paradigmákban, ha ezt nem akadályozná a saját magunk által önként vállalt piacimádat (egy újabb árucikk, amelyet nagyrésঞt az USA exportál, ám ott csupán egészen visszafogottan és pragmatikusan fogyasztják!).

Noha még ezek a szerény javaslatok is maguk után vonhatják a konzervativizmus vádját, most az egyszer egyáltalán nem bánjuk, ha azoknak a táborába kerülünk, akik megpróbálják megvédeni és erôsíteni a legmagasabb szintú, nyilvános tudományos kutatások állami támogatásának rendszerét, amit túlságosan gyakran fenyeget mind a „tulajdonjog” jelszavával folyó gyarmatosítás, mind a „gyakorlati hasznosság” hirdetése. Emellett igyekszünk pragmatikusan felfogni azt a szerepet, amit az állami politika játszhat az innovációs lehetőségek egyre növekvő tárházának hatékony megcsapolására képes nagyvállalati szereplók megerôsödésének elốmozdításában.

\section{Irodalom}

Archibugi, D. - Coco, A. (2005): Measuring technological capabilities at the country level: A survey and a menu for choice. Research Policy, 34 (2), 175-194.

Arrow, K. J. (1962): Economics of Welfare and the Allocation of Resources for Invention. In The Rate and Direction of Inventive Activity. R. Nelson (ed.) 609-25. Princeton: N. J. Princeton University Press.

Arundel, A. - Geuna, A. (2004): Proximity and the Use of Public Science by Innovative European Firms. Economics of Innovation and New Technology, 13, 559-580.

Bush, V. (1945): Science: The Endless Frontier. Washington DC: Government Printing Office.

Cohen, W. M. - Nelson, R. R. - Walsh, J. P. (2002): Links and Impacts: The Influence of Public Research on Industrial R \& D. Management Science, 48 (1), 1-23.

Dasgupta, P. - David, P. A. (1994): Toward a new economics of science. Research Research, 23, 487-521.

David, P. A. (1993): Knowledge property and the system dynamics of technological change. In Proceedings of the World Bank Conference on Development Economics. Eds. Summers, L. - Shah, S. 215-248.

David, P. A. (2004): Understanding the emergence of open science institutions: functionalist economics in historical context. Industrial and Corporate Change, 13 (3), 571-589. 
Dernis, H. - Guellec, D. (2001): Using Patent Counts for Cross-country Comparisons of Technology Output. Science Technology Industry Review, 27, 129-146.

Dernis, H. - Khan, M. (2005): Triadic Patent Families Methodology. STI Working Paper, n. 2004/2.

Dosi, G. (1982): Technological Paradigms and Technological Trajectories: A Suggested Interpretation. Research Policy, 11, 147-162.

Dosi, G. (1988): Sources, Procedures and Microeconomic E_ects of Innovation. Journal of Economic Literature, 26, 1120-1171.

Dosi, G. - Orsenigo, L. - Mazzuccato, M. (2005): The Dynamics of Knowledge Accumulation, Regulation, and Appropriability in the Pharma-Biotech Sector: some Policy Issues. Forthcoming in Innovation, Growth and Market Structure in High-Tech Industries: the Case of BiotechPharmaceuticals. Eds. Dosi, G. - Mazzuccato, M. Cambridge: Cambridge University Press.

Dosi, G. - Llerena, P.- Labini, M. Sylos (2005): Science-Technology-Industry Links and the "European Paradox": Some Notes on the Dynamics of Scientific and Technological Research in Europe. LEM Working Paper.

European Commission (1995): Green Paper on Innovation.

European Commission (2003): Third European Report on Science $\mathbb{E}$ Technology Indicators. Directorate-General for Research.

European Commission (2004): Europe and Basic Research. Communication from the Commission, November.

Florida, R. (1999): The Role of the University: Leveraging Talent, Not Technology. Issues in Science and Technology, summer, 67-63.

Freeman, C. (1982): The Economics of Industrial Innovation. London: Francis Pinter.

Freeman, C. (1994): The economics of technical change: a critical survey. Cambridge Journal of Economics, 18, 1-50.

Freeman, C. - L. Soete (1997): The Economics of Industrial Innovation. Third Edition. Cambridge: MIT Press.

Garfield, E. (1996): How can impact factors be improved? British Medical Journal, 313, 411-413.

Geuna, A. - Salter, A. - Stainmuller, W. E. (2003): Science and Innovation: Rethinking the Rationale for Funding and Governance. Cheltenham: Edward Elgar.

Jaffe, A. B. - Lerner, J. (2004): Innovation and Its Discontents. Princeton: Princeton University Press.

Heller, M. - R. Eisenberg (1998): Can Patents Deter Innovation? The Anticommons in Biomedical Research. Science, 280, 698-701.

Kealey, T. (1996): The Economic Lawes of Scientific Research. New York: St. Martins Press.

King, D. A. (2004): The Scientific Impact of Nations. Nature, 430, 311-316.

Klevorick, A. K. - Levin, R. C. - Nelson, R. R. - Winter, S. G. (1995): On the sources and significance of interindustry differencies in technological opportunities. Research Policy, 24 (2), 185-205.

Kline, S. J. - Rosenberg, N. (1986): An Overview of Innovation. In The Positive Sum Strategy: Harnessing Technology for Economic Growth. Washington DC: National Academy Press.

Malerba, F. (2004): Sectoral Systems of Innovation. Cambridge: Cambridge University Press.

May, R. M. (2004): Raising Europes Game. Nature, 430, 831-832.

Merton, R. K. (1973): The Sociology of Science: Theoretical and Empirical Investigations. Chicago: University of Chicago Press.

Mowery, D. C. - Sampat, B. N. (2005): Universities in National Innovation Systems. In The Oxford Handbook of Innovation. Eds. Fagerberg, J. - Mowery, D. C. - Nelson, R. R. Oxford: Oxford University Press. 209-239.

Mowery, D. - R. Nelson (1999): Sources of Industrial Leadership. Cambridge: Cambridge University Press. 
Mowery, D. C. - Rosenberg, N. (1993): The U. S. National Innovation System. In Nelson (1993).

Narin, F. - Hamilton, K.- Olivastro, D. (1997): The Increasing Linkage between U. S. Technology and Public Science. Research Policy, 26, 317-330.

Nelson, R. R. (1959): The Simple Economics of Basic Scientific Research. Journal of Political Economy, 67 (2), 297-306.

Nelson, R. R. (1993): National Systems of Innovation. Oxford: Oxford University Press.

Nelson, R. R. (2003): On the uneven evolution of human know-how. Research Policy, 32 (6), 909-922.

Nelson, R. R. (2004): The Market Economy, and the Scientific Commons. Research Policy, 33 (3), $455-471$.

Nelson, R. R. - Winter, S. G. (1982): An Evolutionary Theory of Economic Change. Cambridge: the Belknap Press of Harvard University Press.

OECD (2003): OECD Science, Technology and Industry Scoreboard. Organization for Economic Co-operation and Development.

OECD (2004a): Main Science and Technology Indicators. Organization for Economic Co-operation and Development.

OECD (2004b): OECD Information Technology Outlook. Organization for Economic Co-operation and Development.

Pavitt, K. (1987): The Objectives of Technology Policy. Science and Public Policy, 14, 182-188. Reprinted in Pavitt (1999) as The nature of Technology. 3-14.

Pavitt, K. (1999): Technology, Management and Systems of Innovation. Northampton: Elgar.

Pavitt, K. (2001): Public Policies to Support Basic Research: What Can the Rest of the World Learn from US Theory and Practice? (And What they Should not Learn). Industrial and Corporate Change, 10 (3), 761-779.

Pavitt, K. (2003): Commentaries. In Geuna et al. (2003).

Polanyi, M. (1962): The Republic of Science. Minerva, 1, 54-74.

Rosenberg, N. (1976): Perspectives on Technology. Cambridge: Cambridge University Press.

Rosenberg, N. (1982): Inside the Black Box: Technology and Economics. Cambridge, Cambridge University Press.

Sakakibara, M. - Branstetter, L. (2001): Do Stronger Patents Induce More Innovation? Evidence from the 1988 Japanese Patent Law Reforms. Rand Journal of Economics, 32 (1), 77-100.

Saxenian, A. (1988): The Cheshire Cat's Grin: Innovation and Regional Development in England. Technology Review, 91, 67-75.

Saxenian, A. (1996): Regional Advantage: Culture and Competition in Silicon Valley and Route 128. Harvard MA: Harvard University Press.

Winter, S. G. (1982): An essay on the theory of production. In Economics and the World Around It. Ed. S. H. Hymans. Ann Arbor: University of Michigan Press.

Winter, S. G. (1987): Knowledge and Competences as Strategic Assets. In The Competitive Challenge. Ed. D. Teece. Cambridge Mass: Ballinger.

Young, A. (2001): Improving Measures of Government Support to Industrial Technology. Science Technology Industry Review, 27, 147-183. 